\section{Marine Geology}

Vol. 234, Issues 1-4, 18 Dec. 2006, Pages 215-231

http://dx.doi.org/10.1016/j.margeo.2006.09.005

(c) 2006 Elsevier B.V. All rights reserved
Archimer, archive institutionnelle de l'Ifremer http://www.ifremer.fr/docelec/

\title{
Shallow gas off the Rhône prodelta, Gulf of Lions
}

\author{
A. García-García a, b, ${ }^{*}$, D. Orange ${ }^{a, b}$, T. Lorenson ${ }^{c}$, O. Radakovitch ${ }^{d}$, T. Tesi ${ }^{e}$, S. Miserocchi ${ }^{\text {, }}$ \\ S. Bernéf, P.L. Friend ${ }^{g}$, C. Nittrouer ${ }^{h}$ and A. Normand ${ }^{f}$
}

\author{
aUCSC, Department of Earth Sciences, Santa Cruz, CA 95064, USA \\ ${ }^{\mathrm{b}}$ AOA Geophysics Inc., Moss Landing, CA 95039, USA \\ 'USGS, Menlo Park, CA 94025, USA \\ ${ }^{\mathrm{d}}$ CEREGE, 13545 Aix-en-Provence, France \\ ${ }^{e}$ CNR-ISMAR, 40129 Bologna, Italy \\ fIFREMER-Brest, 29280 Plouzané, France \\ ${ }^{9}$ School of Ocean and Earth Science, University of Southampton, SOC, Southampton SO14 3ZH, UK \\ ${ }^{\mathrm{h}} \mathrm{S} c h o o l$ of Oceanography, University of Washington, Seattle, WA 98195, USA \\ *: Corresponding author :
}

\begin{abstract}
:
Sediment cores acquired in 2004 off the Rhône prodelta show consistent anomalous methane concentrations of up to $87,440 \mathrm{ppm}$. Methane compositional and isotopic data support a biogenic origin, although there are a few sites that show strongly depleted $\delta^{13} \mathrm{C}$ values (-53\% PDB) suggesting a mixed source for the gas (biogenic and thermogenic). Anomalous methane concentrations (samples with more than $90 \mathrm{ppm}$ ) are discussed and integrated with organic carbon data, sedimentary rates and ADCP profiles. Highest gas concentrations were found directly off the river mouth (20-40 $\mathrm{m}$ water depth) and where the IFREMER models point to the thickest accumulation $(>2 \mathrm{~m})$ in response to the Rhône flood event.

In areas unaffected by the high flux of organic matter and rapid/thick flood deposition, or in between flood events, the conditions for methanogenesis and gas accumulation have not been met; in these areas, the physical and biological reworking of the surficial sediment may effectively oxidize and mineralize organic matter and limit bacterial methanogenesis in the sub-surface. We propose that in the Rhône prodelta flood deposits deliver significant amounts of terrigenous organic matter that can be rapidly buried, effectively removing this organic matter from aerobic oxidation and biological uptake and leading to the potential for methanogenesis with burial.
\end{abstract}

Keywords: shallow gas; biogenic methane; flood deposits; Rhône prodelta; Gulf of Lions 


\title{
Shallow gas off the Rhône prodelta, Gulf of Lions
}

\author{
García-García $^{1,2}$, A., Orange ${ }^{2,1}$, D., Lorenson ${ }^{3}$, T., Radakovitch ${ }^{4}$, O., Tesi ${ }^{5}$, T., \\ Miserocchi $^{5}$, S., Berné ${ }^{6}$, S., Friend ${ }^{7}$, P. L., Nittrouer ${ }^{8}$, C., Normand $^{6}$, A. \\ ${ }^{1}$ UCSC, Department of Earth Sciences, Santa Cruz, CA 95064, USA; ${ }^{2}$ AOA \\ Geophysics Inc., Moss Landing, CA 95039, USA; ${ }^{3}$ USGS, Menlo Park, CA \\ 94025, USA; ${ }^{4}$ CEREGE, 13545 Aix-en-Provence, France; ${ }^{5}$ CNR-ISMAR, \\ 40129 Bologna, Italy; ${ }^{6}$ IFREMER-Brest, 29280 Plouzané, France; ${ }^{7}$ School of \\ Ocean and Earth Science, University of Southampton, SOC, Southampton \\ SO14 3ZH, UK; ${ }^{8}$ School of Oceanography, University of Washington, Seattle, \\ WA 98195, USA.
}

\section{Abstract}

Sediment cores acquired in 2004 off the Rhône prodelta show consistent anomalous methane concentrations of up to $87440 \mathrm{ppm}$. Methane compositional and isotopic data support a biogenic origin although there are a few sites that show strongly depleted $\delta^{13} \mathrm{C}$ values (-53\% PDB) suggesting a mixed source for the gas (biogenic and thermogenic). Anomalous methane concentrations (samples with more than 90 ppm) are discussed and integrated with organic carbon data, sedimentary rates and ADCP profiles. Highest gas concentrations were found directly off the river mouth (20-40 m water depth) and where the IFREMER models point to the thickest accumulation ( $>2 \mathrm{~m}$ ) due to the Rhône flood event.

In areas unaffected by the high flux of organic matter and rapid/thick flood deposition, or in between flood events, the conditions for methanogenesis and gas accumulation have not been met. In these areas, the physical and biological reworking of the surficial sediment may effectively oxidize and mineralize organic matter and limit bacterial methanogenesis in the subsurface. We propose that in the Rhône prodelta flood deposits deliver significant amounts of terrigenous 
organic matter that can be rapidly buried, effectively removing this organic matter from aerobic oxidation and biological uptake, and leading to the potential for methanogenesis with burial.

Keywords: shallow gas, biogenic methane, flood deposits, Rhône prodelta, Gulf of Lions

\section{Introduction}

Deltaic environments are characterized by very high rates of sediment accumulation and are the gateway by which much of the world's terrigenous organic matter is delivered to the marine environment. Anaerobic bacterial methanogenesis of this buried organic matter can lead to the generation of shallow gas in sediments where sulfate reduction and methane production dominate decomposition (Berner, 1980; Martens and Klump, 1984). If present in sufficient concentrations to exceed solubility, shallow gas can impact impedance contrasts in the sub-surface, the bathymetry and backscatter of the seafloor, and the backscatter within the water column (Hovland and Judd, 1988). As part of the EuroSTRATAFORM program, we have been evaluating the causes of anomalous sub-surface and seafloor features, and specifically, quantifying shallow gas and identifying its impact on geophysical properties in northern Gulf of Lions (GoL), West Mediterranean Sea.

A considerable set of high-resolution data of the GoL has been published so far, such as detailed morpho-bathymetric charts (Berné et al., 2001, 2004) or studies based on high-resolution reflection-seismic datasets, to aid understanding of the Quaternary stratigraphic setting (Chiocci et al., 1997; Gensous and Tesson, 1996; Lobo et al., 2004; Migeon et al., 2001; Rabineau et al., 1998; Tesson et al., 1990, 2000).

Extensive studies about recent processes, sedimentation and circulation in the GoL, in particular related to the Grand Rhône river delta sediments have also 
been published in the last years (Marty et al., 2001; Beaudouin et al., 2004; Petrenko et al., 2005; Estournel et al., 1997, 2001; Radakovitch et al., 1999; Thill et al., 2001). In the present paper we discuss the occurrence of shallow gas evidences in the recent sediments off the Grand Rhône prodelta.

One of the goals of our sampling program was to understand the relationship between flood deposition, primary productivity, and gas (methane) formation. The two main mechanisms for methane formation are: low-temperature bacterial methanogenesis, and high-temperature kerogen thermal cracking (Friedman et al., 1992). In geological literature, the gas generated by the decomposition of organic matter by anaerobic microbes at low temperatures is commonly referred to as 'biogenic' gas, which is distinguished from 'thermogenic' gas by its composition and isotopic signature (Kotelnikova, 2002). Biogenic gas has a high concentration of methane relative to other hydrocarbons (more than $99 \%$; Claypool and Kaplan, 1974; Vogel et al., 1982) and a very depleted (light) stable carbon isotope $\left({ }^{13} \mathrm{C}\right)$ content $\left(\delta^{13} \mathrm{C}\right.$ PDB $<-25$ per mil; Schoell, 1983; Whiticar et al., 1986).

\section{Background}

The continental margin in the GoL is characterized by relatively low annual sediment inputs which are irregularly discharged over the years (Courp and Monaco, 1990). The Grand Rhône river is the dominant (80\%) source of sediment for the continental shelf. The mean long-term suspended particulate discharge of the Grand Rhône is $7.4 \times 10^{6}$ tons/y, with an important variability (1 to $10 \times 10^{6}$ ) related to the hydrological regime of the river (Pont et al., 2002). The $\mathrm{GoL}$ is a modern wave-dominated shelf where the tidal range is only a few $\mathrm{cm}$, and waves have moderate energy (Rabineau et al., 1998). The largest swell is from the south-east, with maximum wave heights of $5 \mathrm{~m}$ and periods of about $8 \mathrm{~s}$, occurring $0.1 \%$ of the time (Rabineau et al., 1998). 
A geostrophic current, known as the Liguro Provençal Current (LPC), flows south-westward along the continental slope. Its average velocity near the seafloor on the outer shelf is $5 \mathrm{~cm} / \mathrm{s}$, but its orientation and magnitude may be modified by seasonal stratification and wind effects, by up to $30 \mathrm{~cm} / \mathrm{s}$ (Millot, 1981; Millot and Crépon, 1981). The LPC has an impact on sediment transport and deposition in the GoL. This current moves westward along the slope at $0.25-0.31 \mathrm{~m} / \mathrm{s}$ in the 0 $100 \mathrm{~m}$ layer, with flow rates from 0.94-2.7 Sv (Bethoux et al., 1998). A northern branch of this current is permanently flooding the shelf area, with a strong impact on the suspended particles from the Grand Rhône plume and on the remobilized sediments (Aloïsi et al., 1979).

On the continental shelf, the associated currents to the LPC are often a few $\mathrm{cm} / \mathrm{s}$ and almost negligible at the surface, when compared to the circulation induced by two strong regional winds (Pinazo et al., 1996); in addition to the western Mediterranean mesoscale circulation, and the fresh water input of the Grand Rhône river, the other main hydrodynamic forces on this continental shelf, are the strong northwestern (tramontane) and northern (mistral) winds (Millot, 1999). The north-west sector winds, induced by a ridge of high pressure over the nearby Atlantic, blow intensively every other day throughout the year, encouraging the formation of coastal upwellings along the north coast (Estournel et al., 1997). The most intense cold water upwelling occurs specifically in front of the area where the Grand Rhône river plume is most likely to flow.

Fresh water inputs in the gulf vary throughout the year, with peaks in rainy seasons, generally spring and fall (Moutin et al., 1998), but the main input is the Grand Rhône river plume (Petrenko et al., 2005), whose direction and extent are greatly affected by the wind (Demarq and Wald, 1984; Estournel et al., 2001; Marsaleix et al., 1998; Naudin et al., 2001). The plume sometimes extends all the way to the Spanish coast (Castellon et al., 1985). In the last 2003 flood event, the peak of the flow of the Grand Rhône was $13000 \mathrm{~m}^{3} / \mathrm{s}$ (Kettner et al., 2004). 
The Grand Rhône drainage basin is $98000 \mathrm{~km}^{2}$, its length is $1100 \mathrm{~km}$, and its water discharge is $1700 \mathrm{~m}^{3} / \mathrm{s}$ (Pont et al., 2002). Its suspended load after the construction of dams is 2-6 $10^{6}$ tons/y, which is much lower than the figure of up to $6010^{6}$ tons/y before the dams were constructed (Chiocci et al., 1997).

The annual budgets of primary production and new production for the GoL shelf are estimated to $71 \pm 7$ and $37 \pm 4 \mathrm{~g} \mathrm{C} / \mathrm{m}^{2}$ (Raimbault and Durrieu de Madron, 2003). This estimation is partly based on monthly measurements done on the shelf break south of the Grand Rhône (Diaz et al., 2000) and do not reflect the variability probably occurring near the Grand Rhône mouth. Gaudy et al. (2003) for example, measured the primary production at various stations of the GoL during two seasonal cruises, and the station located south of the Grand Rhône mouth presented the lowest of the entire area in April 1998 (196 mg C m-2 d-1) but the highest in January 1999 (499 $\left.\mathrm{mg} \mathrm{C} / \mathrm{m}^{2} \mathrm{~d}^{1}\right)$. The mean secondary production for the entire $\mathrm{GoL}$ are estimated to $54 \mathrm{mg} \mathrm{C} / \mathrm{m}^{2} \mathrm{~d}^{1}$ in spring and 19 $\mathrm{mg} \mathrm{C} / \mathrm{m}^{2} \mathrm{~d}^{1}$ in winter, corresponding to $11-12 \%$ of the primary production (Gaudy et al., 2003). The GoL is characterized by a phosphorus-deficiency, which limits the nitrate utilization by phytoplankton and is the main factor controlling primary productivity (Diaz et al., 2001).

Based on ${ }^{210} \mathrm{~Pb}$ dating, the maximum accumulation rates estimated for the Grand Rhône delta sediments range from $40 \mathrm{~cm} / \mathrm{y}$ at the top of the delta front to 0.2 $\mathrm{cm} / \mathrm{y}$ on the continental shelf, decreasing rapidly seawards with preferential SSW direction from the mouth in relation to the spreading of surface and bottom nepheloid layers in the area (Radakovitch et al., 1999). In a broader study in the GoL, Miralles et al. (2005) studied the apparent sedimentation rates, measuring $0.65 \mathrm{~cm} / \mathrm{y}$ in the vicinity of the Grand Rhône river and $0.01 \mathrm{~cm} / \mathrm{y}$ in the deep basin.

IFREMER has modeled the bathymetry off the Grand Rhône prodelta previously, and after the main flood in December 2003 (Maillet et al., this volume). The authors acquired bathymetric data off the mouth of the river before and after the 
flood. The subtraction of the values gives the sedimentary rate of the flood event. The model shows flood-related sedimentation mainly localized off the river mouth, having the maximum sedimentation (more than $2 \mathrm{~m}$ ) in the closest area to the Grand Rhône, which corresponds with areas where the high methane content is found in our samples. Although more studies need to be done, the flood-related deposition event seems to correlate to the high content of methane found some months after the flood occurred.

At present, High Stand deposits off the Grand Rhône river mouth form the Epicontinental Sedimentary Prism (ESP, Aloïsi, 1986). This EPS is the result of the interaction of fluvial and marine processes and is a 40-50 m thick fan-shaped lobe than thins seawards (Rabineau et al., 2005).

\section{Biogenic gas}

In marine sediments, the degradation of organic matter by bacteria is coupled to the consumption of free oxygen, nitrate, manganese, iron oxyhydroxid and sulfate (Berner, 1980; Böttcher et al, 2000). Organic matter oxidation is driven mainly by microbial activity with dissolved sulfate as the final electron acceptor (Jørgensen, 1982), and this leads to the formation of hydrogen sulfide. Although methane can form anywhere in the sediment column, it does not accumulate in appreciable quantities until the dissolved sulfate is consumed because sulfate-reducing bacteria also consume methane. As a result, the maximum rate of anaerobic methane oxidation typically occurs at the base of the sulfate-reducing zone (Blair and Aller, 1995; Iversen et al., 1987; Reeburgh and Alperin, 1988).

The factors that favor significant generation of biogenic gas are rapid sediment deposition, sufficient pore space for methanogenic bacteria (which require $\sim 1 \mu \mathrm{m}$; Boone et al., 1993), and abundant organic matter (Rice, 1993). Hydrogen-rich and bioavailable organic substrates are associated with young, shallow sediments (Kotelnikova, 2002) which typically have the pore space to support methanogenic bacteria. Biogenic gas formation requires an anoxic environment 
with available $\mathrm{CO}_{2}$ and low sulfate concentrations (Oremland, 1988) with temperatures in the range of $9^{\circ} \mathrm{C}$ (Kotelnikova et al., 1998) to $110^{\circ} \mathrm{C}$ (Huber et al., 1994; Stetter, 1992). The upper temperature limit is associated with the maximum conditions at which subsurface methanogens are active. Biogenic methane can be accumulated in large and commercially significant quantities; Rice (1992) estimates that $20 \%$ of the worldwide reserves of natural gas are generated by decomposition of organic matter via anaerobic bacteria.

Although present day shelf seas make up $8 \%$ of the total ocean surface area, about one-fifth to one-third of the global marine primary production takes place in these coastal areas (Wollast, 1991). Shelves therefore are potentially important sinks for large amounts of organic carbon and the formation of biogenic gas. There is some disagreement, however, about the fate of this carbon.

Submarine deltas that supply large amounts of fine grained sediments, and the shelf area proximal to deltas, are sites of increased sediment accumulation and organic matter burial. Ingall and Van Cappellen (1990) suggest that organic matter buried at high accumulation rates can avoid even the most efficient decomposition mechanisms, and would therefore be less degraded than organic matter buried at lower accumulation rates. Deltas, therefore, could provide regions with efficient delivery of organic matter to methanogenic bacteria.

In contrast to the direct correlation of sediment accumulation and carbon preservation proposed for most delta environments, Aller (1998) suggests that deltas can alternatively be characterized by efficient decomposition of organic matter, with decomposition percentages of $\geq 70 \%$ (terrestrial) and $\geq 90 \%$ (marine). Despite high primary productivity and organic input associated with most deltas, Aller (1998) demonstrated that on the deltas studied the reactivity of organic material is low, and a larger proportion of organic carbon is often degraded compared to other marine deposits of similar net accumulation rate. The primary cause of efficient remineralization is intense physical and biological reworking of sediment associated with oceanographic fronts, upwelling, tides, 
bioturbation and waves, as well as the cometabolism of refractory carbon upon burial with relatively reactive carbon (Aller, 1998). Although Aller (1998) documents efficient decomposition of organic matter in deltaic environments, Aller and Blair (2004) note that terrestrial material dominates the slower overall net loss of organic carbon from particles in the topset-upper foreset zone of submarine deltas. De Haas et al. (2002), in a review of shelf environments, concluded that during repeated cycles of erosion and redeposition of organic matter and associated sediments, biological and chemical processes lead to mineralization of more than $95 \%$ of the organic carbon supplied by primary production and fluvial input. Furthermore, a significant percentage of the finegrained sediments containing organic carbon on the shelf can be removed by currents and waves.

\section{Shallow gas and indirect evidences off the Grand Rhône river}

Fluid expulsion can change the local seafloor physiography by either creating local bathymetric highs (pinnacles, mounds, mud volcanoes) or lows (pockmarks), and also by triggering sediment failure (Hovland and Judd, 1988). Gas bubbling into the water column induces a distinctive signature on singlebeam or side scan systems (Hornafius et al., 1999; Hovland and Judd, 1988; MacDonald et al., 2002). On high-resolution seismic records, regions of anomalous gas concentrations in the sub-surface may be associated with anomalous seismic character (originally proposed by Løseth et al., 2003; Heggland, 1998; Hovland et al., 1999; and Schüler, 1952; note that anomalous seismic character may also be caused by variations in attenuation and resonance). Such anomalies are caused by saturated fluids and/or free gas migrating through porous rocks, which may affect the density and/or compressional velocity of the sediment (and therefore the impedance), or the scattering of seismic wave energy. Normal impedance contrasts present in marine sediments may be disrupted or completely occluded by the presence of gas-rich pore fluids, leading to "acoustic blanking" or "acoustic wipeout" (Hovland and Judd, 1988). 
In the northern GoL indirect evidence for potential gas has been reported as 'Tables' facies, in particular in all the prodelta areas up to $60 \mathrm{~m}$ depth (Aloïsi, 1986). Different types of acoustic masking in high resolution seismic records are common features of the Grand Rhône river. In the inner shelf, the prodeltaic sediments (0-30 m water depth) are essentially thin-layered silty muds (Chassefiere, 1990). Near the shoreline the prodeltas are frequently formed of 'bubble-muds' rich in methane which escapes instantly upon physical disturbance, associated with muds enriched in plant debris and peats (Aloïsi and Monaco, 1980).

Gas bubbles and gas-related seeping structures in the area are also known through fishermen and the scientific community, although no specific study about shallow gas off the Grand Rhône river had been done until now.

In November 2003 an Acoustic Doppler Current Profiler (ADCP) survey off the river mouth showed anomalies in the water column (possibly gas?) linked to bed features (see figure 1). In the average ADCP backscatter profiles of the Grand Rhône delta top and front areas, several interesting anomalies were observed in the water column near the sea bed, some of which appeared to be linked with slump features.

\section{Methodology}

We evaluated cores from the Grand Rhône prodelta by sub-sampling the basal portion of kasten cores, fluchat and box cores. Station locations are designated by a letter indicating the coring transect (each transect is oriented approximately perpendicular to isobaths), and a number indicating approximate water depth, from 14 to $94 \mathrm{~m}$ (see figure 2). Cores sub-sampled for shallow gas were acquired with the following research vessels: R/V Antedon II, R/V Tethys II, and R/V Oceanus in February, March and October of 2004 respectively. 
Cores were sampled for headspace gas in the following manner:

A 5-cm-long section near the base of the core was removed and placed into a metal can equipped with a septum and weighed. Next, the sample can was filled with water to the rim and $100 \mathrm{~mL}$ of water was removed. About 2 to 3 grams of sodium chloride salt was added as a bacteriacide. The sample and water were sealed in the can leaving a $100 \mathrm{~mL}$ headspace. The sealed can was then inverted and frozen. Frozen samples were transported to the organic geochemistry laboratory at the U.S.G.S. in Menlo Park, California where they were placed in a freezer. Samples were stored frozen until they were thawed, processed and analyzed. Headspace analyses can provide an assessment of the constituents in a gas ( $\mathrm{C} 1, \mathrm{C} 2+$, etc.), as well as a relative determination of gas concentrations. In this study, headspace analyses were conducted on a single sample from a core (typically the deepest undisturbed region). Although this sample may not be representative of the entire core, our experience has shown that the deepest sample, which has the highest probability of being below the methane oxidation sulfate reduction horizon, typically has the highest gas concentrations.

Because headspace analyses measure gas concentrations on cores that are not pressurized (and thus can de-gas on their way to the surface), the measurements provide a minimum estimate of the amount of gas in a sample; absolute gas concentrations require pressurized sampling equipment to keep the gas from coming out of solution during ascent through the water column. For these samples, which originate in relatively shallow water, the headspace gas analyses would more closely relate to the actual concentration of gas than cores recovered from deeper water. Recovered samples with low concentrations of gas may be below saturation both at their original depth and at the sea surface. Headspace analyses of these samples may better reflect in situ gas concentrations. Note that the isotopic composition of the carbon in the methane would change very little even if there were degassing. 
In the laboratory, the frozen samples in cans were allowed to thaw until they reached about $20^{\circ} \mathrm{C}$, then placed into a high-speed shaker and shaken for 5 minutes. The partitioned hydrocarbon gases in the headspace were analyzed for methane through hexane ( $\mathrm{C} 1-\mathrm{C} 6$ ), $\mathrm{CO}_{2}$, and $\mathrm{H}_{2} \mathrm{~S}$ by gas chromatography. Samples with more than $90 \mathrm{ppm}$ methane are considered to be anomalous; background methane values in this and similar coastal environments are usually less than about $30 \mathrm{ppm}$.

The coring programs included a total of 56 cores from 49 distinct locations offshore the Grand Rhône prodelta in the GoL (Figure 2). Core recovery on all samples was excellent, with up to $216 \mathrm{~cm}$ in the kasten cores.

Cores were sampled for organic matter (OM) analysis in the following manner:

Subcores, taken from box-corer, were extruded onboard ship into 0-1 cm intervals. Only the uppermost (surficial) and the lowermost (bottom) sediment slices were used in this study. The lowermost slice is analogous to the sample collected for the gas analysis. Sediment samples for elemental and isotopic analyses were collected from sub-cores and refrigerated during transport back to the laboratory, then stored frozen until analysis. In the laboratory, the sample was dried at $55^{\circ} \mathrm{C}$ and ground to pass through a $250 \mu \mathrm{m}$ sieve prior to analysis.

Organic carbon (OC) and total nitrogen (TN) concentrations were obtained using a FISONS NA2000 Element Analyzer after removal of the carbonate fraction in silver capsules by dissolution in $\mathrm{HCl} 1.5 \mathrm{~N}$. The average standard deviation of each measurement, determined by replicate analysis of the standard, is $\pm 0.02 \mathrm{wt} \%$. C: $\mathrm{N}_{\mathrm{a}}$ is the atomic OC/ TN ratio. Stable isotope analyses of organic carbon were carried out on the same samples by using a FINNIGAN Delta Plus mass spectrometer, which was directly coupled to the FISONS NA2000 EA by means of a CONFLO interface for continuous flow measurements. The IAEA standard NBS19 was used as calibration material for carbon. Uncertainties were lower than $\pm 0.2 \%$, as determined from routine 
replicate measurements of the reference sample $\mathrm{CH}-7$ (IAEA). Stable-isotope data are expressed in the conventional delta notation in which the ${ }^{13} \mathrm{C} /{ }^{12} \mathrm{C}$ isotopic ratios are reported relative to the international PDB standard.

\section{Results}

During 2004, several cruises acquired a total of 56 samples off the Grand Rhône prodelta. On these cruises cores were acquired for multiple purposes, including shallow gas studies (this paper), flood deposit studies, sediment accumulation rates, detailed sedimentological analysis, etc. That allowed us to have a more integrated understanding of the shallow gas in the area.

Headspace gas analysis

February-March 04 cruises

The samples were located widely spaced off the Grand Rhône mouth, between 20 and $90 \mathrm{~m}$ of water (see figure 2), and all the samples were taken at $25-30 \mathrm{~cm}$ below the actual seafloor (the bottom of a Fluchat core). With a background value for methane in this area of $90 \mathrm{ppm}$, only 4 of the 18 samples have a very low methane content ( $<50 \mathrm{ppm}$; figure 2 and table 1 ), samples located to the east and to the southwest of the river mouth. Values higher than the background- ranging from $100 \mathrm{ppm}$ to $600 \mathrm{ppm}$ - are mostly located perpendicular from the river mouth discharge and also in a northeast-southwest trend (see figure 2), with the higher ones on the west side. This westward trend mimics the main current circulation of the area. The high peaks of methane are specifically located off the Grand Rhône mouth, with methane values ranging 3950 to 33720 ppm (Table 1). As can be observed in figure 2, the two highest gas values, in sites Ch30 and 05, were found directly off the Grand Rhône mouth.

$54 \%$ of the 18 samples (8) showed very anomalous gas (approx. $>400 \mathrm{ppm}$ ) and were further analyzed for their isotopic composition (see table 1). The $\delta^{13} \mathrm{C}$ (relative to PDB) of the methane ranges from -59.9 to $-81.9 \%$ for six of the 
eight sites. The other two show relatively heavier $\delta^{13} \mathrm{C}$ values (-53\% PDB), suggesting a mixed source for the gas. Methane and $\mathrm{CO}_{2}$ carbon isotopic composition considered in tandem demonstrate that the methane was likely generated by carbonate $\left(\mathrm{CO}_{2}\right)$ reduction by microbes, a common process in marine sediments. Site 06 had a $\delta^{13} \mathrm{C}$ value of $-53.1 \%$, indicating that gas might be borderline biogenic/thermogenic in origin. We revisited that location in October 04 to acquire more data to confirm that mixed origin.

\section{October 04 cruise}

In the fall of 2004 we cored off the Grand Rhône mouth at 32 different sites and took a total of 38 samples (see figure 2). We used box cores and kasten cores for that purpose and the headspace gas analysis results can be seen in table 1. First of all, most of the samples had much higher value of gas than the background, and 25 samples had more than 1000 ppm (figure 2). In general, the closer the samples were to the river mouth, the higher the gas content was; and in general the 'Fall' samples were gassier than the 'Spring' ones. Most of the samples were taken at the bottom of a box core-approximately $30 \mathrm{~cm}$ below seafloor. However, in two locations, (sites E28 and E33), we re-sampled the site with a kasten core. With several samples deeper in the core, we can study gas variations through time within the core. In those cores, the methane values increased as we deepened into the sediment, reaching (in sites E28 and E33) extremely high values of 87440 and $81330 \mathrm{ppm}$ at the bottom of the core respectively (approximately at $210 \mathrm{~cm}$ depth within the core, see figure 2).

Of the 38 Fall samples, the majority of the samples (34) yielded high gas concentrations (89\%) and were sent for isotope analysis. Although at the time of submission, we are still waiting on those results, we expect to get the same results for the source of the gas-mostly biogenic-as in previous data (FebruaryMarch04).

In most of the Grand Rhône samples, the sediment immediately below the sediment-water interface was dark colored, with a moderate to strong $\mathrm{H}_{2} \mathrm{~S}$ smell. 
The presence of strong $\mathrm{H}_{2} \mathrm{~S}$ suggests that at that location the depth to the base of the sulfate reduction zone is shallow, possibly indicating upward advection of reduced fluids (and gas). All of the highest gas concentrations occur in the region of rapid and thick flood deposition proximal to the mouth of the Grand Rhône river (figure 3, see Maillet et al. in this volume for further information). Anomalous gas concentrations were found in all core types, both shallow (fluchat and box cores) and deeper in the sediment (kasten cores). At sites E281 and E33, kasten cores had higher gas values than the co-located box or fluchat core (ex. Box core E33 had $23210 \mathrm{ppm}$ of $\mathrm{C} 1$ and the same site sampled at $216 \mathrm{~cm}$ had $81330 \mathrm{ppm}$ of C1). In all cases, though, both core types (shallow and deeper) showed anomalous concentrations at the same location.

Acoustic anomalies in high-resolution seismic records are common off the prodelta river (see figure 4). As shown in the profile, the acoustic blanking coincides with one site we box-cored for gas (E56) with a high value of $5420 \mathrm{ppm}$ of methane. The availability of more seismic data in the future, will allow groundtruthing of the acoustic anomalies found on the records, with direct methane indications.

\section{Organic carbon analysis}

The ranges of all organic parameters are presented in Table 2. In the surficial sediment, OC contents are inversely related to distance from the mouth of the river, such that the highest \% OC values $(\approx 1.44 \%$ ) are observed at the inshore stations and going westward, while the lowest OC contents ( $\approx 1.03 \%)$ are observed at the offshore stations (Figure 5). A strong, linear relationship exists between organic carbon and total nitrogen contents of all surface sediments $\left(r^{2}\right.$ $=0.83)$. It is noteworthy that the $x$-intercept $(\% O C=0)$ of this regression is 0.16 , therefore close to zero, which indicates that the majority of nitrogen in these sediments is associated with organic matter (e.g., Hedges et al., 1986). 
The $\delta^{13} \mathrm{C}$ pattern distribution is similar to that observed for $\mathrm{OC}$, in that the lowest values were measured at the inshore stations ( $\approx-26.83 \%$ ), while the highest values are observed at the offshore stations ( $\approx-25.85 \%$ ) (see figure 6). $\mathrm{C}: \mathrm{N}_{\mathrm{a}}$ values show a similar trend along the prodelta area decreasing seaward.

In the bottom samples, there is not any clear trend that distance from land presents marked changes in the $\% O C, \delta^{13} \mathrm{C}$ and $\mathrm{C}: \mathrm{N}_{\mathrm{a}}$ values in samples. Likely these samples have a different time scale for deposition, and they reflect dissimilar sedimentation events.

\section{Discussion}

Our headspace gas data confirms the presence of anomalous gas in the areas where the sub-bottom data shows acoustic wipeout (Aloïsi, 1986). One of the 3.5 $\mathrm{kHz}$ sub-bottom profiler lines the author studied displays the 'tables' facies in a line than runs perpendicular to the river mouth. In that same study, the records also show evidence of acoustic plumes in the water column, apparently coming directly from the zone of acoustic blanking in the $3.5 \mathrm{kHz}$ profiles, indicating areas where the gas may be seeping to the water column. In line STR-100 acoustic anomalies off the river mouth are clearly visible (see figures 3 and 4). This is the location of site E56, which yielded a high value of methane (5420 ppm). Note that the acoustic anomalies reach to the seafloor and the sample was taken from a box core.

Potential gas-related escape features have also been identified by an ADCP survey (Figure 1). In front of the river mouth, several features have been identified as resulting from gas seepage. Although those specific locations were too shallow for us to core, it is reasonable to think they are gas seepage-related, as high gas concentration was found in shallow sediments just $100 \mathrm{~m}$ away from those features. 
A gas concentrations in a core higher than 1-2\% is suggested to be the lower limit necessary for acoustic wipeout (Fannin, 1980; Løseth et al., 2003; note that in the western Baltic, acoustic turbidity is associated with less than $0.5 \%$ gas; Abegg and Anderson, 1997; Missiasen et al., 2002). Spring cores BF05, BF06, BF09 and Chenal30 and most of the Fall cores have gas concentrations higher than 1-2\% (see table 1). In addition, most of the Spring cores and all of the Fall cores have values higher than the $\sim 30 \mathrm{ml} / \mathrm{l}$ suggested to be the lower limit of gas necessary to create acoustic turbidity / wipeout based upon borehole samples correlated with sub-bottom profiler data in the Gulf of Mexico (Whelan III et al., 1978).

The lack of other hydrocarbons ( $\mathrm{C} 2+)$ in the headspace gas analyses suggests a microbial origin of the gas off the Grand Rhône. Site 06 had a $\delta^{13} \mathrm{C}$ value of $53.1 \%$ PDB, such a figure being on the borderline of a thermogenic origin.

Our data indicate that thermogenic hydrocarbons are not a significant component of the gas present on the Grand Rhône prodelta. Methane isotopic composition in the headspace gas analyses further support to a biogenic origin $\left(\delta^{13} \mathrm{CH}_{4}(\mathrm{PDB})\right.$ of -53.1 to $-81.9 \%$ ). Note that some of these values are more negative than expected (-80\% is standard). The headspace gas values of $\delta^{13} \mathrm{CO}_{2}$ and $\delta^{13} \mathrm{CH}_{4}$ are as expected for shallow marine sediments high in organic matter (>1\% TOC). The $\delta^{13} \mathrm{CO}_{2}$ values analyzed in conjunction with the $\delta^{13} \mathrm{CH}_{4}$ values define the kind of bacterial process responsible for the formation of the methane. In the case of the Grand Rhône samples $\left(\delta^{13} \mathrm{CO}_{2}=-18\right.$ to -67$)$, carbonate reduction $\left(\mathrm{CO}_{2}+\mathrm{H}_{2}=\right.$ $\mathrm{CH}_{4}$ ) is interpreted to be the microbial process generating methane.

\section{OM Discussion}

Vascular plants, from land, exhibit many bulk chemical and isotopic proprieties that distinguish them from marine organisms (Hedges and Oades, 1997). For example, the predominance of nitrogen-free biomacromolecules (e.g. tannin, lignin, cellulose, cutin and suberin) over proteins $\left(C: N_{a} \approx 3-4\right)$ makes higher 
plant tissues characteristically carbon-rich (C: $\mathrm{N}_{\mathrm{a}} \approx 20-500$ ) versus phytoplankton (C: $\mathrm{N}_{\mathrm{a}} \approx 6.6$; Redfield et al., 1963) and bacteria (C: $\mathrm{N}_{\mathrm{a}} \approx 4$ ) (Hedges et al., 1997). The organic matter adsorbed by soil, shows a value between vascular plants and bacteria (C: $\left.\mathrm{N}_{\mathrm{a}} \approx 8-14\right)$ (Hedges and Oades, 1997). Carbon isotopic signatures can distinguish organic matter photosynthesized by plants $\left(\delta^{13} \mathrm{C} \approx-25 \% \cdot-28 \%\right.$ PDB $)$ using the $\mathrm{C} 3$ pathway of $\mathrm{CO}_{2}$ uptake, versus temperate marine phytoplankton $\left(\delta^{13} \mathrm{C} \approx-22 \%-18 \%\right.$ PDB) (Fry and Sherr, 1984; Mook and Tan, 1991). The soil value depends on the original $\mathrm{C} 4$ or $\mathrm{C} 3$ plant material which formed the deposit $\left(\delta^{13} \mathrm{C} \approx-27.5 \%\right.$ $25.00 \%$ PDB, general value for the European forest soil, Novàk et al., 2003).

Interpreting our data set in terms of two-end member mixing of terrigenous OM $\left(\delta^{13} \mathrm{C} \approx-27 \%\right.$ ) with typical marine sources $\left(\delta^{13} \mathrm{C} \approx-20 \%\right)$, the surficial distribution in October 04 shows that the origin of sedimentary OM in front of Grand Rhône river is strictly dominated by the riverine input, presenting less riverine origin going offshore and going westward (less pronounced) following general pattern of circulation (LPC) (figure 6b).

Interestingly cores taken near sites 06 and E33 (east of the mouth of the river), were found to contain significant undergraded plant remains (canne de provence, leaves) at about 10-20 cm depth (CEREGE, personal communication), overlying sandy/silty sediments. Such fresh and abundant plant accumulation of vegetals (with high porosity) can explain the very high methane content found in those sites.

The isotopic distribution seems to be spatially coincident with the thickness of the sediment deposited during the October 03 flood (estimated from IFREMER model) even taking into account that the samples were collected almost one year later. This could be explained with the isotopic distribution reflecting the progressive dilution of terrestrial $\mathrm{OM}$ with marine $\mathrm{OM}$. The range of $\delta^{13} \mathrm{C}$ and C: $N_{a}$ surficial values is narrow (s.d $\delta^{13} \cdot C= \pm 0.25, s . d C: N_{a}= \pm 0.88$ ) and roughly all samples are to be considered of terrigenous origin as the $\mathrm{C}: \mathrm{N}_{\mathrm{a}}$ mean is 
almost twice compare to Redfield ratio and the $\delta{ }^{13} \mathrm{C}$ mean is close to the $\mathrm{C} 3$ plant signature.

In the surficial sediments the distribution of organic isotopic composition reflects the dispersal pattern of the $\mathrm{OC}$ concentration (Figure 7). Clearly, there is a correlation $\left(R^{2}=0.73\right)$ between $O C$ and $\delta^{13} C$, with the highest terrestrial concentration of $\mathrm{OC}$ in front of the mouth of the Grand Rhône where there is the highest concentration of gas. A possible explanation could be the presence of woody debris or flocs that are generally concentrated in front of the river mouth. Therefore it seems clear the $\delta^{13} \mathrm{C}$ is a good tracer for the terrigenous organic matter in this prodelta area.

Bottom samples do not show the same correlation: likely this is due to the different depositional time scale among the samples and/or the differential effect of OC degradation (different degradation rates or selective degradation among the isotopes ${ }^{13} \mathrm{C}$ and ${ }^{12} \mathrm{C}$ ).

There is not a linear correlation between the concentration of the $\mathrm{C} 1$ gas with the amount of organic carbon or with the isotopic signature (see figure 8). This means that probably the gas collected from the bottom of the box core migrated from lower in the sediment, and this is a process driven not only by the quality of the sedimentary organic matter $\left(\mathrm{OC}, \delta^{13} \mathrm{C}\right.$ and $\left.\mathrm{C}: \mathrm{N}_{\mathrm{a}}\right)$ but also by the thickness of the material delivered from the river.

\section{Comparison Grand Rhône and Po prodeltas}

Within the EuroSTRATAFORM frame, shallow biogenic gas was also sampled on the active topset and foreset of the Po delta in Western Adriatic Sea (Orange et al., 2005). Cores acquired on the Po delta yielded gas data that successfully ground-truthed the interpreted relationship between anomalous reflectivity in high-resolution sub-bottom data, and shallow gas. Off the Po delta, and prior to a flood event, highly flocculated, organic rich sediment is deposited in the near 
field, and reworked in the mobile upper layer of sediment giving high floc fraction low carbon sediments. During a flood the plume extends out over the shelf, increasing bottom stress in the near field, so that deposition is dominated by single grain settling. Coarse-grained particulate carbon would be deposited with the silt fraction at this time, resulting in low floc fraction carbon-rich sediments. As flow decreases, floc settling would be re-established, capping the coarse carbon fraction with a relatively impervious layer of fine-grained sediment. In between flood events organic carbon is delivered to the seabed with the floc fraction. At low sediment accumulation rates, this material could be reworked by physical and biological processes, such that the floc fraction gets digested by benthic organisms and/or oxidized, and doesn't survive long enough to be broken down biogenically to form shallow gas.

Palinkas et al. (2005) found that within the Po delta the maximum sedimentary rates $-6 \mathrm{~cm} / \mathrm{s}$ - occurred off the main river mouth - the Pila mouth. Off the Po delta, the flood peak was $7000 \mathrm{~m}^{3} / \mathrm{s}$, lower than the flood peak found for the Grand Rhône plume - 13000 m³/s- (Kettner et al., 2004). The IFREMER model shows more than $2 \mathrm{~m}$ of flood deposits of the Grand Rhône mouth. Although more work is needed, the flood-related sedimentary rates off the Rhône river are expected to be higher than the ones found off the Po river.

Away from the Po delta, and along the western Adriatic, it is suggested that the recent deposits are thinner and within the reach of physical and biological reworking, allowing for remobilization or mineralization of organic matter (García-García et al., in press). As a result, anomalous gas concentrations are more related to methanogenesis deeper in the section, perhaps related to the maximum flooding surface below the recent sedimentary mud wedge, and anomalous gas concentrations are unrelated to recent direct inputs from land. This is what we expect to happen as we move away from the Grand Rhône flood influence, particularly in the southwestern area of the GoL. Future work will confirm this but, clearly the intensity of the Grand Rhône floods compared 
to the Po floods, would suggest that we expect a bigger difference between the flood and non-flood areas in the GoL as well.

Table 3 is a presentation of the summarized data $\left(\mathrm{OC}, \delta^{13} \mathrm{C}, \mathrm{C}: \mathrm{N}_{\mathrm{a}}\right)$ of the sediment collected off the mouth of the Grand Rhône. We have compared the bulk compositions of this surficial and bottom material with averages of the surficial sediment collected in the prodelta Po in different seasons (Miserocchi et al., in press). In the prodelta of the Grand Rhône the average content of OC is slightly higher $\left(\mathrm{OC}_{\mathrm{Grand} \mathrm{Rhône}}=1.23 \% \pm 0.21, \mathrm{OC}_{\mathrm{Po}_{\mathrm{O}}}=1.00 \pm 0.26\right)$, whilst $\delta^{13} \mathrm{C}$ and $\mathrm{C}: \mathrm{N}_{\mathrm{a}}$ values are clearly different compared to the averages found off the Po river mouth $\left(\delta^{13} \mathrm{C}_{\text {Grand Rhône }}=-26.23 \% \pm \pm 0.30 ; \delta^{13} \mathrm{C}_{\mathrm{Po}_{0}}=-25.01 \pm 0.79\right.$; C: $\left.N_{\text {Grand Rhône }}=11.07 \pm 0.70, C: N_{P_{0}}=10.0 \pm 1.6\right)$. At a first look more negative values in $\delta^{13} \mathrm{C}$ and more positive values in $\mathrm{C}: \mathrm{N}_{\mathrm{a}}$ show that the origin of the material off the Grand Rhône prodelta is more terrestrial as compared to that of the material collected in the Po area. It would be necessary to define the terrigenous and marine end-members for both systems, in order to better understand the behaviour of organic matter..

\section{Conclusions}

High methane contents characterize surficial sediment off the Rhône prodelta (up to $87440 \mathrm{ppm}$ ). The highest gas content is suggested to be related to flood events, where models show more than $2 \mathrm{~m}$ of sediments. In places, this biogenic gas shows mixed origins, suggesting migration from deeper sources.

The stable carbon isotopic signature, and elemental composition of the sedimentary organic matter in the prodelta area, show the clear influence of terrigenous supply which slightly decreases away from the mouth of the Grand Rhône following the regional pattern of the current dynamics.

Although still preliminary, we suggest a similar scenario for both, the Northern Gulf of Lions and the Western Adriatic prodeltaic environments. The gas found off 
the main river is flood-related, however away from the main river, the gas seems to have a deeper source. All indications are, that away from the flood-influenced Grand Rhône prodelta, in areas where all the highest gas concentrations occur, the sites will have less methane, or the gas will be deeper within the sediments, indicating that it is non flood-related

\section{Acknowledgements}

We thank all of the scientific staff from the R/V Antedon II, R/V Tethys II, and R/V Oceanus as well as our EuroSTRATAFORM colleagues for their collaboration and assistance, in particular Delphine Pierre from IFREMER. The research herein was funded by the U.S. Navy through the Office of Naval Research EuroSTRATAFORM project (contract number N00014-03-1-142, Orange). We thank Isabelle Herbert for revision of the final manuscript. Constructive reviews by Dr. Cattaneo and an anonymous reviewer have greatly improved the manuscript. We kindly thank Dr. Trincardi for his help and support. We thank the University of Victoria (M. Whiticar) for isotopic analyses of headspace gases. Jennifer Dougherty assisted with headspace gas analyses at the USGS. This is ISMAR-IGM (CNR) scientific contribution number 1502.

\section{References}

Abegg, F., Anderson, A.L., 1997. The acoustic turbid layer in muddy sediments of Eckernförde Bay, Western Baltic: methane concentration, saturation and bubble characteristics. Mar. Geol. 137, 137-147.

Aller, R.C., 1998. Mobile deltaic and continental shelf muds as suboxic, fluidized bed reactors. Mar. Chem. 61, 143-155.

Aller, R.C., Blair, N.E., 2004. Early diagenetic remineralization of sedimentary organic $\mathrm{C}$ in the Gulf of Papua deltaic complex (Papua New Guinea): Net loss of 
terrestrial $\mathrm{C}$ and diagenetic fractionation of $\mathrm{C}$ isotopes. Geochim. et Cosmochim. Acta 68 (8), 1815-1.825.

Aloïsi, J.C., Millot, C., Monaco, A., Pauc, H., 1979. Dynamique des suspensions et mécanismes sédimentologiques sur le plateau continental du Golfe du Lion. Comptes Rendus de l'Académie des Sciences de Paris, 289 D, 879-882.

Aloïsi, J.C., Monaco, A., 1980. Etude des structures sédimentaires dans les milieux deltaïques (Grand Rhône). Apport à la connaissance des conditions de sédimentation et de diagenèse. Comptes Rendís de l'Académie des Sciences de Paris, 290D, 159-162.

Aloïsi., J.C., 1986. Sur un Modèle de Sédimentation Deltaïque. Contribution à la connaissance des marges passives. Unpublished thesis. Université de Persignan, France, $162 \mathrm{pp}$.

Aucour, A.-M., Sheppard, S.M.F., Guyomar, O., Wattelet, J., 1999. Use of ${ }^{13} \mathrm{C}$ to trace origin and cycling of inorganic carbon in the Grand Rhône river system. Chem. Geol. 159, 87-105.

Beaudouin, C., Dennielou, B., Melki, T., Guichard, F., Kallel, N., Berné, S., Huchon, A., 2004. The Late-Quaternary climatic signal recorded in a deep-sea turbiditic levee (Grand Rhône Neofan, Gulf of Lions, NW Mediterranean): palynological constrains. Sedim. Geol. 172, 85-97.

Berné, S., Carré, Loubrieu, B., Mazé, J.-P., Morvan, L., Normand, A., 2004. Le Golfe du Lion. Carte Morpho-bathymétrique. Echelle 1/250000, Éditions Ifremer, Plouzané, France. 
Berné, S., Carré, Loubrieu, B., Mazé, J.-P., Normand, A., 2001. Le Golfe du Lion. Carte Morpho-bathymétrique. Cartes et Atlas. Region Languedoc Rousillon. Echelle 1/100000, Éditions Ifremer, Plouzané, France.

Berner, R.A., 1980. Early Diagenesis: A theoretical Approach, Princenton University Press, 241 pp.

Bethoux, J.P., Prieur, L., Bong, J.H., 1998. Le courant Ligure au large de Nice. Oceanol. Acta sp, 59-67.

Blair, N.E., Aller, R.C., 1995. Anaeroic methane oxidation on the Amazon shelf. Geochim. et Cosmochim. Acta 59, 3707-3715.

Boone, D.R., Whitman, W.B., Rouviere, P., 1993. Diversity and taxonomy of methanogens. In: Ferry, J.G. (Ed.), Methanogenesis. Chapman \& Hall, London, $35-81$.

Böttcher, M.E., Hespenheide, B., Llobet-Brossa, E., Beardsley, C., Larsen, O., Schramm, A., Wieland, A., Böttcher, G., Berninger, U.-G., Amann, R., 2000. The biogeochemistry, stable isotope geochemistry, and microbial community structure of a temperate intertidal mudflat: an integrated study. Cont. Shelf Res. 20, 17491769.

Calmet, D., Fernandez, J.-M., 1990. Caesium distribution in northwest Mediterranean seawater, suspended particles and sediments. Cont. Shelf Res. 10 (9-11), 895-913.

Castellon, A., Salat, J., Maso, M., 1985. Some observations on Grand Rhône fresh water plume in the Catalan coast. In: CIES (Ed.), Rapp. Comm. Int. Mer Medit. Monaco, pp. 119-121. 
Cauwet, G., Gadel, F., de Souza Sierra, M.M., Donard, O., Ewald, M., 1990. Contribution of the Grand Rhône River to organic carbon inputs to the northwestern Mediterranean sea. Cont. Shelf Res. 10 (9-11), 1025-1037.

Chassefiere, B., 1990. Mass-physical properties of surficial sediments on the Grand Rhône continental margin: implications for the nepheloid benthic layer. Cont. Shelf Res. 10 (9-10), 857-867.

Chiocci, F.L., Ercilla, G., Torres, J., 1997. Stratal architecture of Western Mediterranean Margins as the result of the stacking of Quaternary lowstand deposits below 'glacio-eustatic fluctuation base-level'. Sedimen. Geol. 112, 195217.

Ciabatti, M., 1967. Ricerche sull'evoluzione del Delta Padano. G. Geol. 34, 381406.

Clayppol, G.E., Kaplan, I.R., 1974. The origin and distribution of methane in marine sediments. Natural Gases in Marine Sediments. Plenum, New York, pp. 99-139.

Courp, T., Monaco, A., 1990. Sediment dispersal and accumulation on the continental margin of the Gulf of Lions: sedimentary budget. Cont. Shelf Res. 10 (9-11), 1063-1087.

Cruzado, A., Velasquez, R., 1990. Nutrients and phytoplankton in the Gulf of Lions, northwestern Mediterranean. Cont. Shelf Res. 10 (9-11), 931-942.

de Haas, H., van Weering, T.C.E., de Stigter, H., 2002. Organic carbon in shelf seas: sinks or sources, processes and products. Cont. Shelf Res. 22, 691-717.

Demarq, H., Wald, L., 1984. La dynamique superficielle du panache du Grand Rhône d'après l'imagerie infrarouge satellitaire. Oceanol. Acta 7(2), 159-162. 
Diaz, F., Raimbault, P., Conan, P., 2000. Small-scale study of primary productivity during spring in a Mediterranean coastal area (Gulf of Lions). Cont. Shelf Res. 20, 975-996.

Diaz, F., Raimbault, P., Boudjellal, B., Garcia, N., Moutin, T., 2001. Early phosphorus limitation during spring in the Gulf of Lions. Mar. Ecol. Progr. Series 211, 51-62.

Durrieu de Madron, X., 1994. Hydrography and nepheloid structures in the Grand Rhône canyon. Cont. Shelf Res. 14 (5), 457-477.

Durrieu de Madron, X., Nyffeler, F., Godet, C.H., 1990. Hydrographic structure and nepheloid spatial distribution in the Gulf of Lions continental margin. Cont. Shelf Res. 10 (9-11), 915-929.

El Sayed, M.A., Aminot, A., Kerouel, R., 1994. Nutrients and trace metals in the northwestern Mediterranean under coastal upwelling conditions. Cont. Shelf Res. 14 (5), 507-530.

Estournel, C., Broche, P., Marsaleix, P., Devenon, J.L., Auclair, F., Vehil, R., 2001. The Grand Rhône river plume under unsteady conditions: numerical and experimental results. Estuar. Coast. and Shelf Sci. 53, 25-38.

Estournel, C., Kondrachoff, V., Marsaleix, P., Vehil, R., 1997. The plume of the Grand Rhône: numerical simulation and remote sensing. Cont. Shelf Res. 17 (8), 899-924.

Fannin, N. G. T., 1980. The use of regional geological surveys in the North Sea and adjacent areas in the recognition of offshore hazards. In: Ardus, D.A., (Ed.), Offshore site investigation, Graham \& Trotman, 5-21. 
Fernex, F., Baratie, R., Span, D., Vandelei Fernandes, L., 1989. Variations of nitrogen nutrient concentrations in the sediment pore waters of the northwestern Mediterranean continental shelf. Cont. Shelf Res. 9 (9), 767-794.

Ferrand, J.-L., Hamelin, B., Monaco, A., 1999. Isotopic tracing of anthropogenic $\mathrm{Pb}$ inventories and sedimentary fluxes in the Gulf of Lions (NW Mediterranean sea). Cont. Shelf Res. 19, 23-47.

Fonseca, L., Mayer, L., Orange, D., Driscoll, N., 2002. The high-frequency backscattering angular response of gassy sediments: Model/data comparisons from the Eel River margin, California. J. Acoust. Soc. Am. 111, 2621-2631.

Friedman, G.M., Sanders, J.E., Kopaska-Merkel, D.C., 1992. Principles of Sedimentary Deposits. Stratigraphy and Sedimentology. MacMillan Publishing Company, New York, 717 pp.

Frignani, M., Courp, T., Cochran, J.K., Hirschberg, D., Vitoria i Codina, L., 2002. Scavenging rates and particle characteristics in and near the Lacaze-Duthiers submarine canyon, northwest Mediterranean. Cont. Shelf Res. 22, 2175-2190.

Fry, B., Sherr, E. B., 1984. $\delta^{13} \mathrm{C}$ measurements as indicators of carbon flow in marine and freshwater ecosystems ecosystems. Contrib. in Mar. Sci. 27, 13-47.

Gadel, F., Puigbó, A., Alcañiz, J.M., Charrière, B., Serve, L., 1990. Tracers and constituents indicating the nature of organic fluxes, their origin and the effect of environmental conditions. Cont. Shelf Res. 10 (9-11), 1039-1062.

García-García, A., Orange, D., Miserocchi, S., Correggiari, A., Langone, L., Lorenson, T., Trincardi, F. Nittrouer, C., in press. What controls shallow gas in Western Adriatic Sea? Cont.Shelf Res. 
Gaudy, R., Youssara, F., Diaz, F., Raimbault, P., 2003. Biomass, metabolism and nutrition of zooplankton in the Gulf of Lions (NW mediterranean). Oceanol. Acta, 26, 4, 357-372.

Gensous, B., Tesson, M., 1996. Sequence stratigrpahy, seismic profiles, and cores of Pleistocene deposits on the Grand Rhône continental shelf. Sedimen. Geol. 105, 183-190.

Hagen, R.A., Vogt, P.R., 1999. Seasonal variability of shallow biogenic gas in Chesapeake Bay, Mar. Geol. 158, 75-88.

Hedges J. I., 1990. Compositional indicators of organic acid sources and reactions in natural environments. Organic Acids in Aquatic Environments, Eds. E. M. Perdue and E. T. Gjessing, pp. 43-63. Wiley and Sons, New York. Hedges, J.I., Clark, W.A., Quay, P.D., Richey, J.E., Devol, A.H., Santos, U.M., 1986. Composition and fluxes of particulate organic material in the Amazon River. Limn. \& Oceanogr. 31, 717-738.

Hedges, J.I., Keil, R.G., 1995. Sedimentary organic matter preservation: an assessment and speculative synthesis. Mar. Chem. 49, 81-115.

Hedges, J.I., Keil, R.G., Benner, R., 1997. What happens to terrestrial organic matter in the ocean? Org. Geochem. 27, 195-212.

Hedges, J.I., Oades, J.M. 1997. Comparative organic geo-chemistries of soils and sediments. Org. Geochem. 27, 319-361.

Heggland, R., 1998. Gas seepage as an indicator of deeper prospective reservoirs. A study based on exploration 3D seismic data. Mar. Petrol. Geol. 137, 41-47. 
Heussner, S., Cherry, R.D., Heyraud, M., $1990 .{ }^{210} \mathrm{Po},{ }^{210} \mathrm{~Pb}$ in sediment trap particles on a Mediterranean continental margin. Cont. Shelf Res. 10 (9-11), 9891004.

Hill, P.S., Milligan, T.G., Geyer, W.R., 2000. Controls on effective settling velocity of suspended sediment in the Eel River flood plume, Cont. Shelf Res. 20, 20952111.

Holland, C.W., 2002. Shallow water coupled scattering and reflection measurements, IEEE J. of Ocean Eng., 27, 454-470.

Hornafius, J.S., Quigley, D.C., Luyendyk, B.P., 1999. The world's most spectacular marine hydrocarbon seeps (Coal Oil Point, Santa Barbara Channel, California): Quantification of emissions. J. Geophys. Res. 20 C9, 20,703-20,711.

Hovland, M., Judd, A.G., 1988. Seabed pockmarks and seepages. Impact on geology, biology and the marine environment. Graham \& Trotman Ltd., London, $293 \mathrm{pp}$.

Hovland, M., Løseth, H., Bjørkum, P.A., Wensaas, L., Arntsen, B., 1999. Seismic detection of shallow high pore pressure zones, Offshore, Dec., 94-96.

Huber, H., Huber, R., Lödermann, H.-D., Stetter, O.K., 1994. Search for hyperhermophilic microorganisms in fluids obtained from the KTB pump test. Sci. Drill. 4, 127-129.

Ingall, E.D., Van Cappellen, P., 1990. Relation between sedimentation rate and burial of organic phosphorus and organic carbon in marine sediments. Geochem. et Cosmochim. Acta 54, 373-386. 
Iversen, N., Oremland, R.S., Klug, M.J., 1987. Big Soda Lake (Nevada): 3. Pelagic methanogenesis and anaerobic methane oxidation. Limnol. Oceanogr. $32,804-814$

Jackson, D.R., Williams, K.L., Wever, T.F., Friedricks, C.T., Wright, L.D., 1998. Sonar backscatter, J. Atmospheric and Oceanic Tech. 9, 630-644.

Jørgensen, B.B., 1982. Mineralization of organic matter in the sea bed - the role of sulphate reduction. Nature 296, 643-645.

Kettner, A.J., Hutton, E.W.H., Syvitski, J.P.M., 2004. Simulating the impact of the 2003 flood event of the Grand Rhône river on the Gulf of Lions, France. EOS Transactions. AGU Fall Meeting 04 abstract.

Kotelnikova, S., 2002. Microbial production and oxidation of methane in deep surface. Earth-Sci. Rev. 58, 367-395.

Kotelnikova, S.V., Macario, A.J.A., Pedersen, K., 1998. Methanobacterium subterraneum, a new alcalophilic, euthermic and halotolerant methanogen isolated from deep granitic groundwater. Int. J. Syst. Bacteriol. 48, 357-367.

Kranck, K., 1984. Grain-size characteristics of turbidites. In: D.A.V. Stow and D.J.W. Piper (Eds) Fine-grained sediment: Deep-water processes and facies. Blackwell Scientific Publications, Oxford. pp 83-94.

Kranck, K., Milligan, T. G., 1991. Grain size in oceanography, in Theory, Methods and Applications of Particle Size Analysis. Syvitski, J. P. (Ed.). Cambridge University Press, New York, pp. 332-345.

Leveau, M., Coste, B., 1987. Impacts des apports Rhodaniens sur le milieu pélagique du Golfe du Lion. Bull. d’Ecol. 18, 119-122. 
Lobo, F.J., Tesson, M., Gensous, B., 2004. Stratal architectures of late Quaternary regressive-transgressive cycles in the Roussillon Shelf (SW Gulf of Lions, France). Mar. Petrol. Geol. 21, 1181-1203.

Løseth, H., Wensaas, L., Arntsen, B., 2003. Gas chimneys - indicating a fractured cap rock. Am. Ass. Petrol. Geol., Abstracts with Programs, 2003.

MacDonald, I.R., Leifer, I., Sassen, R., Stine, P., Mitchell, R., Guinasso Jr., N., 2002. Transfer of hydrocarbons from natural seeps to the water column and atmosphere. Geofluids 2, 95-107.

Maillet, G., Vella, C., Berné, S., Friend, P.L., Amos, C.L., Fleury, T.J., Normand, A., this volume. Morphological changes and sedimentary processes induced by the December 2003 flood event at the present mouth of the Grand Rhône River (southern France). Marine Geology.

Marchetti, M., 2002. Environmental changes in the central Po Plain (northern Italy) due to fluvial modifications and anthropogenic activities. Geomorphology $44,361-373$.

Marsaleix, P., Estournel, C., Kondrachoff, V., Vehil, R., 1998. A numerical study of the formation of the Grand Rhône River plume. Jour. Mar. Sys. 14 (1-2), 99115.

Martens, C.S., Albert, D.B., Alperin, M.J., 1998. Biogeochemical processes controlling methane in gassy coastal sediments - Part 1. A model coupling organic matter flux to gas production, oxidation and transport. Cont. Shelf Res. 18, 1741-1770.

Martens, C.S., Klump, J.V., 1984. Biochemical cycling in an organic-rich coastal marine basin 4 . An organic carbon budget for sediments dominated by 
sulfate reduction and methanogenesis. Geochim. et Cosmochim. Acta 48, 1987-2004.

Marty, D., Bonin, P., Michotey, V., Bianchi, M., 2001. Bacterial biogas production in coastal systems affected by freshwater inputs. Cont. Shelf Res. 21, 2105-2115.

Mayer, L., 1994. Surface area control of organic carbon accumulation in continental shelf sediments. Geochim. et Cosmochim. Acta 58 (4), 1271-1284.

Migeon, S., Savoye, B., Zanella, E., Mulder, T., Faugères, J.-C., Weber, O., 2001. Detailed seismic-reflection and sedimentary study of turbidite sediment waves on the Var Sedimentary Ridge (SE France): significance for sediment transport and deposition and for the mechanisms of sediment-wave construction. Mar. Petrol. Geol. 18, 179-208.

Millot, C., 1981. La dynamique marine du lateau continental du golfe du Lion en étè. University of Paris 6, Unpublished Doctor thesis.

Millot, C., 1999. Circulation in the Western Mediterranean Sea. Jour. Mar. Sys. 20, 423-442.

Millot, C., Crépon, M., 1981. Inertial oscillations on the continental shelf of the Gulf of Lions. Observations and theory. Jour. Phys. Oceanogr. 11, 639-657.

Miralles J., Radakovitch O., Aloïsi J.C., 2005. 210Pb sedimentation rates from the northwestern mediterranean margin. Mar. Geol. 216, 155-167.

Miserocchi S., Langone L., Tesi T. (in press) Content and isotopic composition of organic carbonwithin a flood layer in the Po River prodelta (Adriatic Sea). Cont. Shelf Res. 
Missiaen, T., Murphy, S., Loncke, L., Henriet, J. -P., 2002. Very high-resolution seismic maping of shallow gas in the Belgian coastal zone. Cont. Shelf Res. 22, 2291-2301.

Monaco, A., Biscaye, P., Soyer, J., Pocklington, R., Heussner, S., 1990a. Particle fluxes and ecosystem response on a continental margin: the 1985-1988 Mediterranean ECOMARGE experiment. Cont. Shelf Res. 10 (9-11), 809-839.

Monaco, A., Courp, T., Heussner, S., Carbonne, J., Fowler, S.W., Deniaux, B., 1990b. Seasonality and composition of particulate fluxes during ECOMARGE-I, western Gulf of Lions. Cont. Shelf Res. 10 (9-11), 959-987.

Mook, W. G., T. C. Tan., 1991. Stable carbon isotopes in rivers and estuaries, pp. 245-264. In E. T. Degens, S. Kempe, and J. E. Richey (eds.), Biogeochemistry of major world rivers, SCOPE. Wiley.

Moutin, T., Raimbault, P., Golterman, H.L., Coaste, B., 1998. The input of nutrients by the Grand Rhône river into the Mediterranean Sea: recent observations and comparison with earlier data. Hydrobiologia 373-374, 237-246.

Naudin, J.J., Cauwet, G., Fajon, C., Oriol, L., Terzic, S., Devenon, J.L., Broche, P., 2001. Effect of mixing on microbial communities in the Grand Rhône River Plume. Jour. Mar. Sys. 28, 203-227.

Orange D., García-García, A., Lorenson, T., Nittrouer, C., Milligan, T., Miserocchi, S., Langone, L., Correggiari, A., Trincardi, F., 2005. Shallow gas and flood deposition on the Po Delta. Mar. Geol. 222-223, 159-177.

Oremland, R.S., 1988. Biochemistry of methanogenic bacteria. In: Zehnder, A.J.B. (Ed.), Biology of Anaerobic Microorganisms. Wiley, New York, pp. 641707. 
Palinkas, C.M., Nittrouer, C.A., Wheatcroft, R.A., Langone, L., 2005. The use of ${ }^{7}$ Be to identify event and seasonal sedimentation near the Po River delta, Adriatic Sea. Mar. Geol. 222-223, 95-112.

Petrenko, A., Leredde, Y., Marsaleix, P., 2005. Circulation in a stratified and wind-forced Gulf of Lions, NW Mediterranean Sea: in situ and modeling data. Cont. Shelf Res. 25, 7-27.

Pinazo, C., Marsaleix, P., Millet, B., Estournel, C., Véhil, R., 1996. Coupled modelling of physical and biological processes in the Gulf of Lions (northwestern Mediterranean): spatial and temporal variability. Jour. Phys. Oceanogr. 23, 164-171.

Pont, D., Simonet, J.P., Walter, A.V., 2002. Medium-term changes in suspended sediment delivery to the ocean : consequences of catchment heterogeneity and river management (Grand Rhône river, France). Estuar. Coast. shelf sci. 54, 1-18.

Rabineau, M., Berné, S., Ledrezen, É., Lericolais, G., Marsset, T., Rotunno, M., 1998. 3D architecture of lowstand and transgressive Quaternary sand bodies on the outer shelf of the Gulf of Lion, France. Mar. Petrol. Geol. 15, 439-452.

Rabineau, M., Berné, S., Aslanian, D., Olivet, J.-L., Joseph, P., Guillocheau, F., Bourillet, J.-L., Ledrezen, É., 2005. Sedimentary sequences in the Gulf of Lion: A record of 100,000 years climatic years. Mar. Petrol. Geol. 22, 775-804.

Radakovitch, O., Charmasson, S., Arnaud, M., Bouisset, P., 1999. ${ }^{210} \mathrm{~Pb}$ and Caesium Accumulation in the Grand Rhône Delta Sediments. Estuar., Coast. Shelf Sci. 48, 77-92. 
Raimbault, P., Durrieu de Madron, X., 2003. Research activities in the Gulf of Lion (NW mediterranean) within the 1997-2001 PNEC Project. Oceanol. Acta, 26, 4, 291-298.

Raiswell, R., 1988. Chemical model for the origin of minor limestone shale cycles by anaerobic methane oxidation. Geology 16, 641-644.

Redfield, A.C., Ketchum, B.H., Richards, F.A., 1963. The influence of organisms on the composition of seawater. In: Hill, M.N. (Ed.), The Sea, Vol. 2. Wiley, New York, pp. 26-77.

Reeburg, W.S., Alperin, M.J., 1988. Studies on anaerobic methane oxidation. Sci. Am. 66, 367-375.

Rice, D., 1992. Controls, Habitat, and Resource Potential of Ancient Bacterial Gas. Bacterial Gas, Vially, R. (Ed.). Editions Technip, Paris, pp. 91-118.

Rice, D.D., 1993. 'Biogenic' gas: controls, habitats, and resource potential. In: Howell, D.G. (Ed.), The Future of Energy Gases. United States government printing office, Washington, pp. 583-606.

Schoell ${ }_{2}$ M., 1983. Genetic characterization of natural gases. AAPG Bull. 67 (12), 2225-2238.

Schüler, F., 1952. Untersuchungen über die Machtigkeit von Schlickschichten mit Hilfe des Echographen. Dt. Hydrographiche Zeitung, 5, 220-231.

Scully, M.E., Friedrichs, C.T., Wright, L.D., 2003. Numerical modeling of gravitydriven sediment transport and deposition on an energetic continental shelf: Eel River, northern California. Jour. Geophys. Res. 108, C4, 3120-3134. 
Stetter, K.O., 1992. Life at upper temperature border. In: Tran Tranh Van, J.K., Mounlou, J.C., Schneider, C., McKay, C. (Eds.), Frontiers of Life. Colloque Interdisciplinaire Comite National de la reserche Scientifique, Gif-sur-Yvette, France, pp. 195-219.

Tesson, M., Gensous, B., Allen, G.P., Ravenne, Ch., 1990. Late Quaternary Deltaic Lowstand Wedges on the Grand Rhône Continental Shelf, France. Mar. Geol. 91, 325-332.

Tesson, M., Posamentier, H.W., Gensous, B., 2000. Stratigraphic organization of Late Pleistocene deposits of the Western part of the Golfe du Lion shelf (Languedoc shelf), Western Mediterranean Sea, using high-resolution seismic and core data. The Am. Ass. Petrol. Geol. Bull. 84 (1), 119-150.

Thill, A., Moustier, S., Garnier, J.-M., Estournel, C., Naudin, J.-J., Bottero, J.-Y., 2001. Evolution of particle size and concentration in the Grand Rhône river mixing zone: influence of salt flocculation. Cont. Shelf Res. 21, 2127-2140.

Traykovski, P., Geyer, W.R., Irish J.D., Lynch, J.F., 2000. The role of waveinduced density-driven fluid mud flows for cross-shelf transport on the Eel River continental shelf. Cont. Shelf Res. 20, 2113-2140.

van Buchum, F.S.P., de Boer, P.L., McCave, I.N., Herbin, J.-P., 1995. The organic carbon distribution in Mesozoic marine sediments and the influence of orbital climatic cycles (English and the western Northern Atlantic). In: Huc, A.Y., Schneidermann, N. (Eds.), Paleogeography, Paleoclimate and Source Rocks, Am. Ass. Petrol. Geol. Spec. Pub. 40, 303-335.

Vogel, T.M., Oremland, R.S., Kvenvolden, K.A., 1982. Low-temperature formation of hydrocarbon gases in San Francisco Bay sediment (California, U.S.A.). Chem. Geol. 37, 289-298. 
Whelan, III, T., Coleman, J.M., Suhayda, J.N., Roberts, H.H., 1978. Acoustical penetration and sheat strength in gas-charged sediment. Mar. Geotech. 2, 147159.

Whiticar, M.J., Faber, E., Schoell, M., 1986. 'Biogenic' methane formation in marine and freshwater environments: CO2 reduction vs. acetate fermentationisotopic evidence. Geochim. et Cosmochim. Acta 50, 693-709.

Wollast, R., 1991. The coastal organic carbon cycle: fluxes, sources and sinks. In: Mantoura, R.F.C., Martin, J.-M., Wollast, R. (Eds.), Ocean Margin Processes in Global Change. Dahlem Workshop Reports. Wiley Interscience, Chichester, pp. 365-381. 


\section{Figure Captions:}

Figure 1. (a) Tracks and track directions of backscatter ADCP profiles off the Grand Rhône mouth, November 2003. The general morphology of the slump features is outlined; (b) profile 8; (c) profile 10; and (d) profile 11. The positions of anomalies in the water column close to the sea bed are indicated, together with the position of the surface hyperpycnal plume. Areas of high backscatter on the delta top are probably caused by wave resuspension. Bed features were interpreted during a geomorphologic study of the delta front (for further details, see Maillet et al. in this volume).

Figure 2. Location of coring sites off the Grand Rhône river. White dots indicate sites sampled in February-March 2004 and black dots correspond to sites sampled in October 2004. Values in parenthesis are ppm of methane. ' $F$ ' indicates samples taken with a Fluchat core and ' $\mathrm{B}$ ' indicates Box core samples Bathymetric lines contours every $10 \mathrm{~m}$. Rest of surveyed sites are shown in inset.

Figure 3. Coring sites and IFREMER swath model indicating the extension of the sedimentary 03'flood-related deposits (see Maillet et al. in this volume); maximum sedimentary deposition up to $3 \mathrm{~m}$. ' $\mathrm{F}$ ' indicates samples taken with a Fluchat core and ' $\mathrm{B}$ ' indicates Box core samples. Values in parenthesis are ppm of methane. Location of seismic line STR-100 is also shown.

Figure 4. Seismic line STR-100 off the Rhône outlet. Acoustic anomalies, potential indicators of shallow gas, are indicated with a 'G'. Site E56 was box cored yielding 5420 ppm of methane (see profile location in figure 3).

Figure 5. Relationship between OC\% (organic carbon) and TN\% (total nitrogen) for surficial and bottom sediments from box-corer. 
Figure 6. Contour maps of organic carbon (a), $\delta^{13} \mathrm{C}(\mathrm{b})$ and $\mathrm{C}: \mathrm{N}$ atomic (c) of surficial sediment in the Rhône prodelta area. Station locations are indicated by crosses.

Figure 7. Relationship between $\mathrm{OC} \%$ and $\delta^{13} \mathrm{C}$ for (a) surficial and bottom sediments from box-corer (b) collected in the prodelta Rhône area. The OC content in the uppermost and the lowermost layers are differently correlated with the $\delta^{13} \mathrm{C}$ due to the dissimilar degradation rates or the selective remineralization among the isotopes ${ }^{13} \mathrm{C}$ and ${ }^{12} \mathrm{C}$.

Figure 8. Relationship between $\mathrm{OC} \%$ and $\mathrm{C} 1 \mathrm{ml} \mathrm{l}-1$ for bottom samples from box-corer. 


\section{Table Captions:}

Table 1. Headspace gas analyses and isotopic results for cores acquired on the Grand Rhône prodelta during 2004 EuroSTRATAFORM cruises. KC for kasten core, BC for box core, and F for fluchat core. Abbreviations: WD, water depth; $\mathrm{SD}$, sample depth, b.s.f., below seafloor.

Table 2. Bulk compositions of surficial and bottom sediments from box-corer collected in the prodelta Grand Rhône area. Abbreviations: OC\%, weight percent total organic carbon; TN\%, weight percent total nitrogen; C:Na, atomic $\mathrm{OC} / \mathrm{TN}$ ratio; $\delta^{13} \mathrm{OC} \%$, stable carbon isotope composition of organic carbon; n.d. ${ }^{a}$, not determined.

Table 3. Summary statistics of organic carbon percentage (\%wt), organic carbon isotopic composition (\%), C:N atomic ratio from superficial sediments in the prodelta Grand Rhône area from box-corer. 

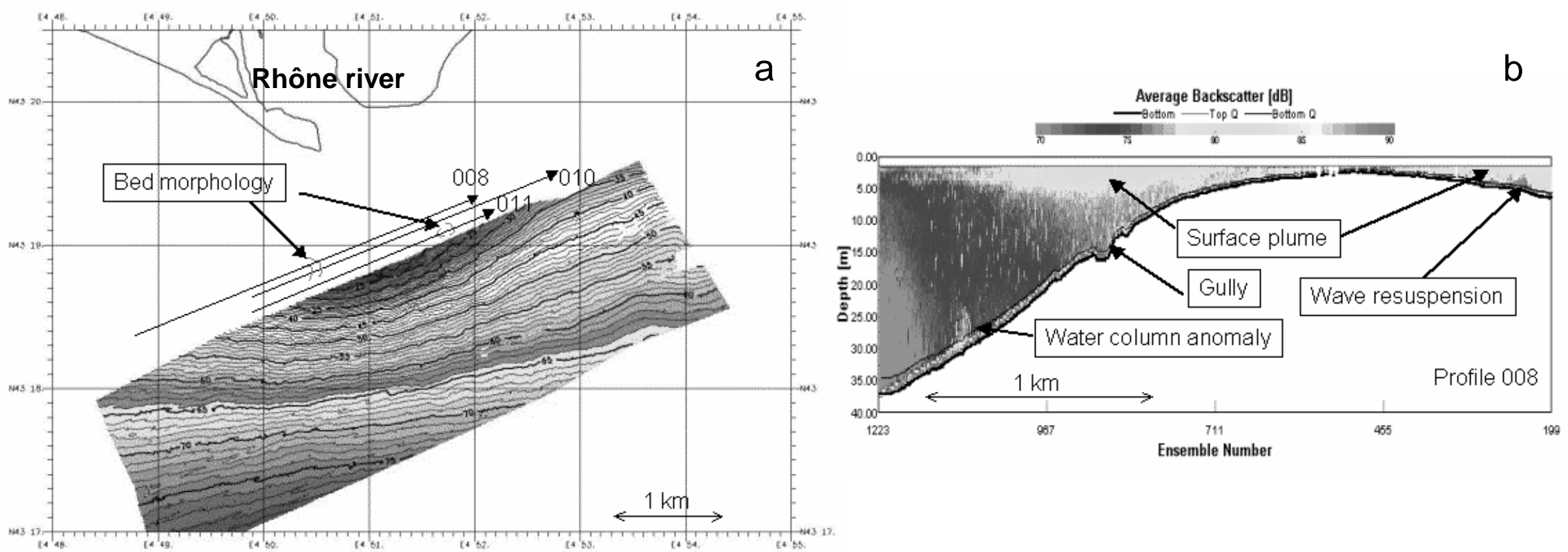

C
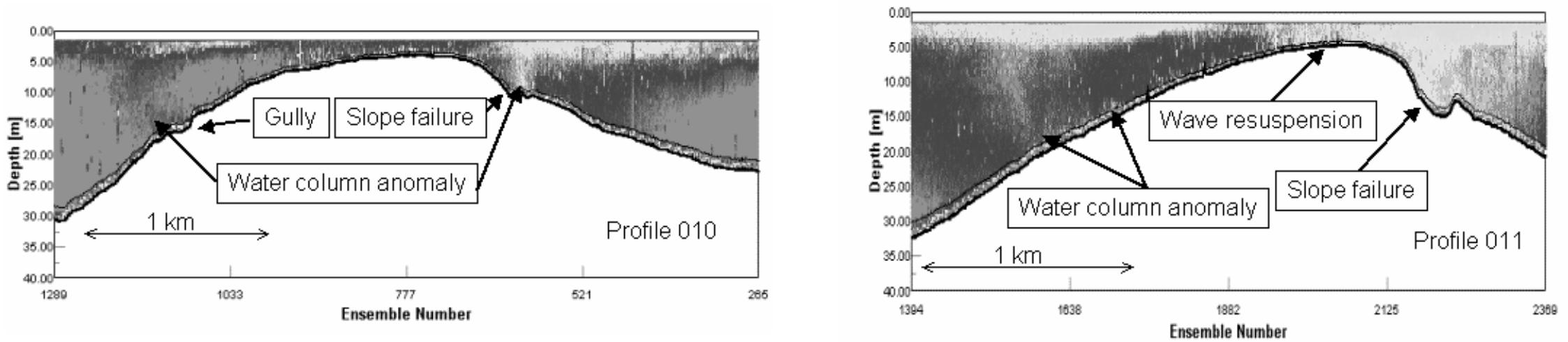


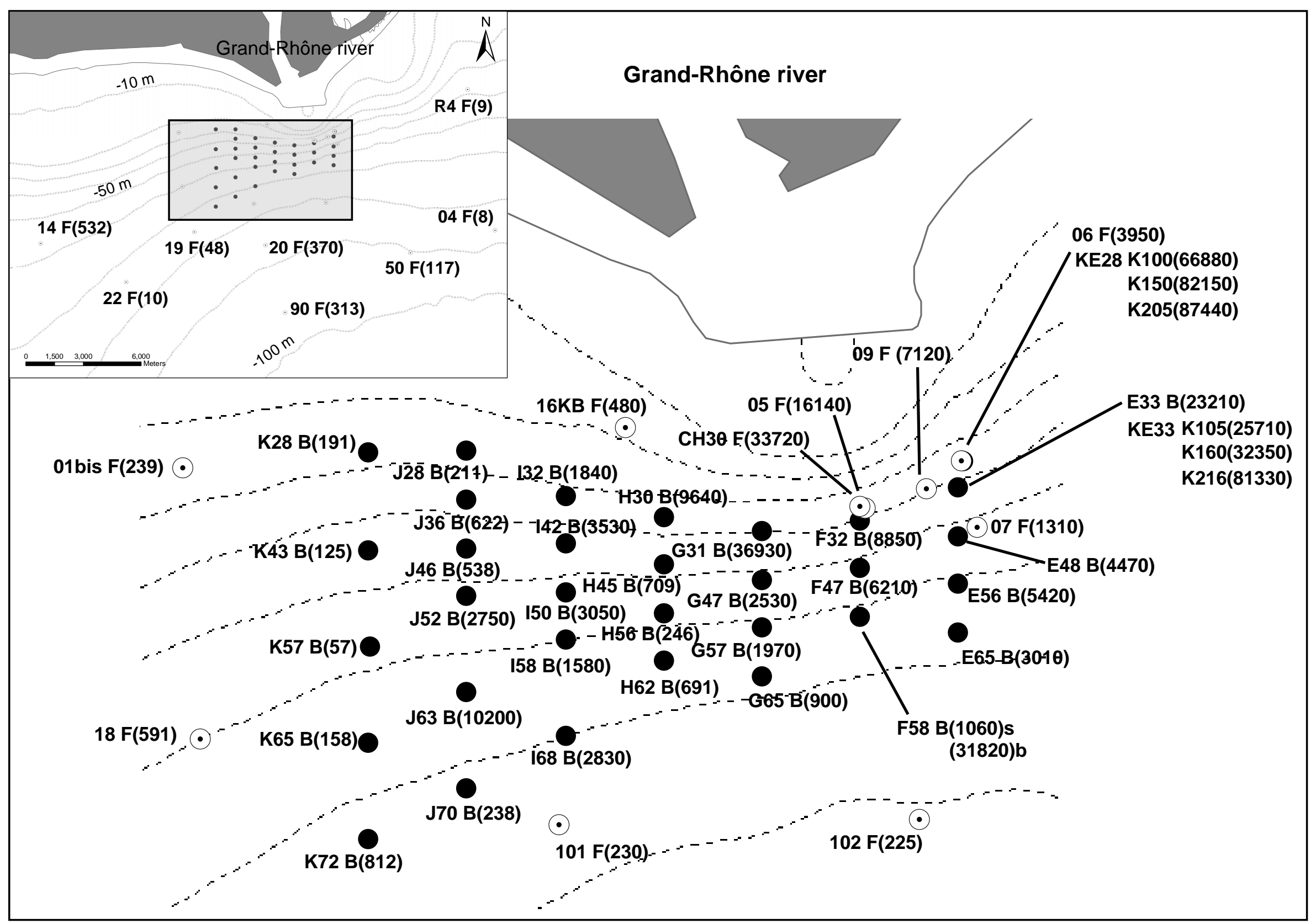




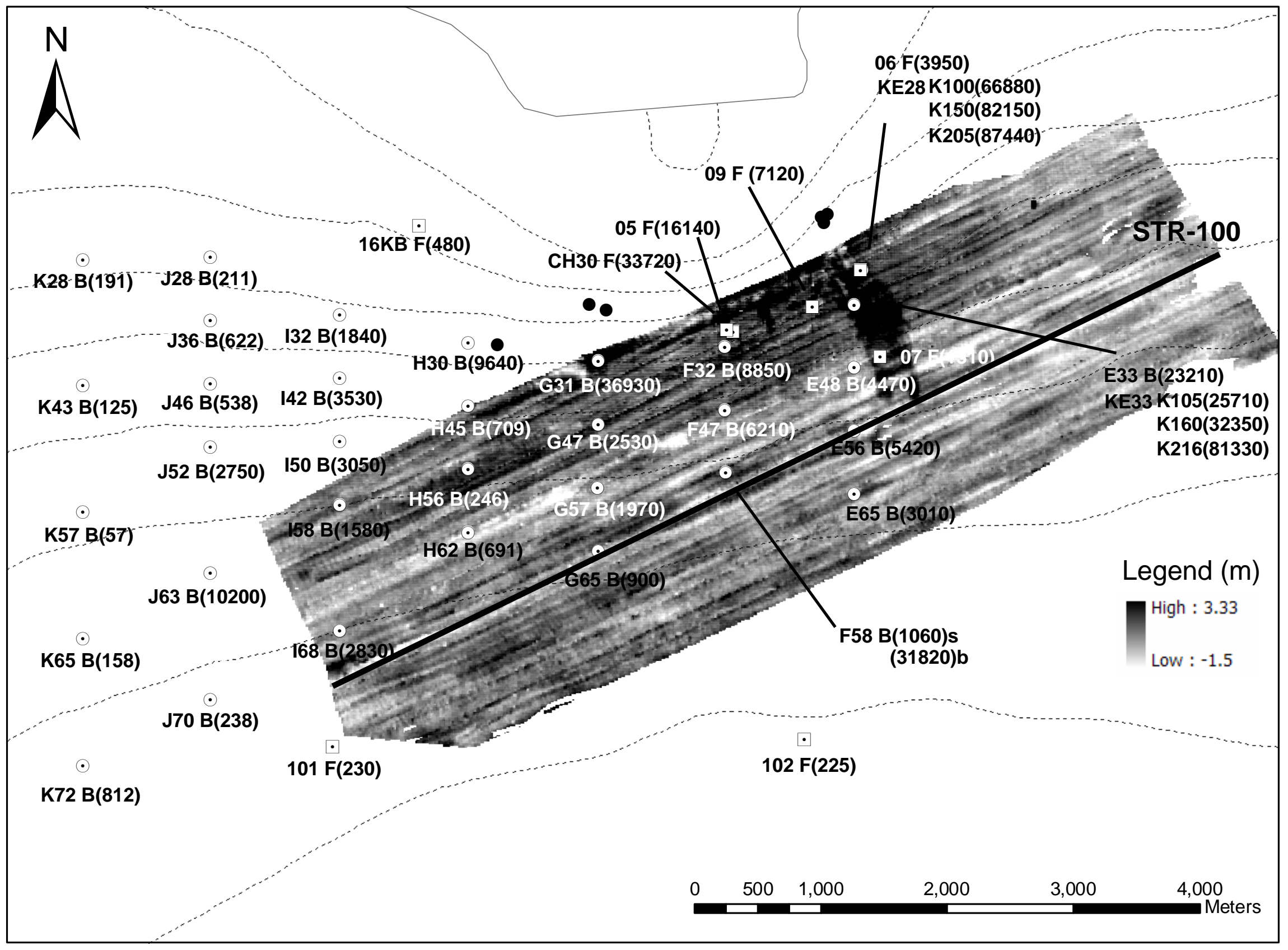


TWTT

(ms)

50 (5)

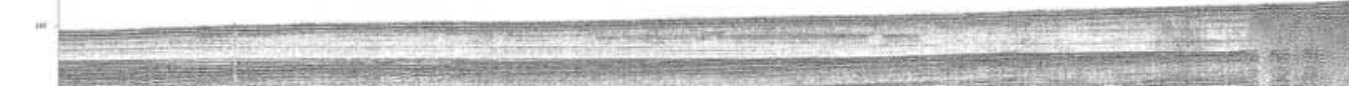

150

"

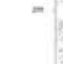

300

$1 \mathrm{~km}$
E56 (5420 ppm C1)

NE

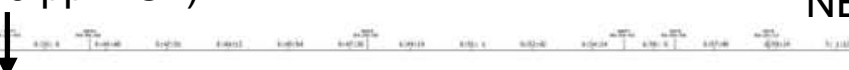

G G G (1)

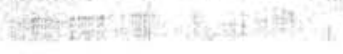




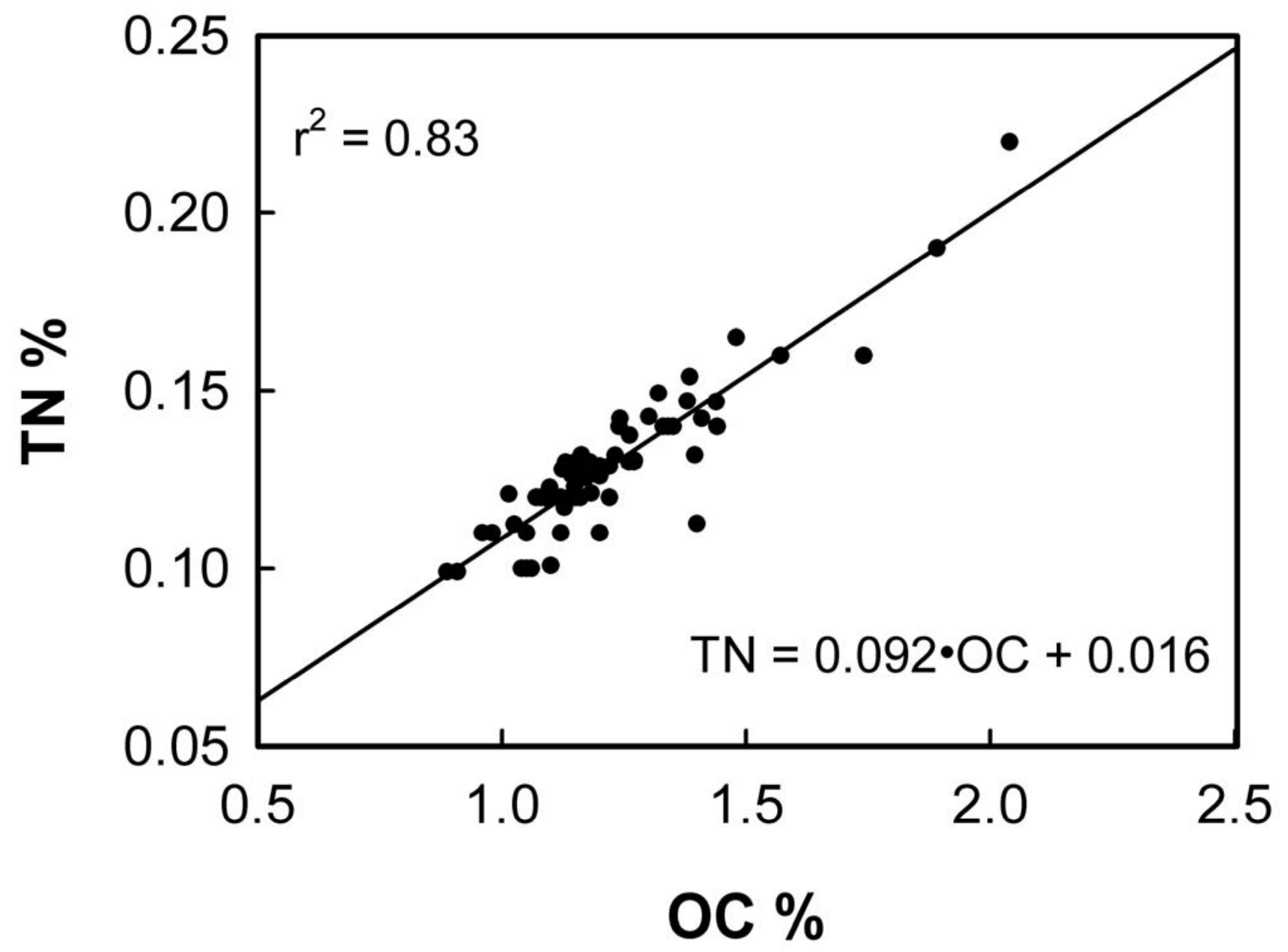



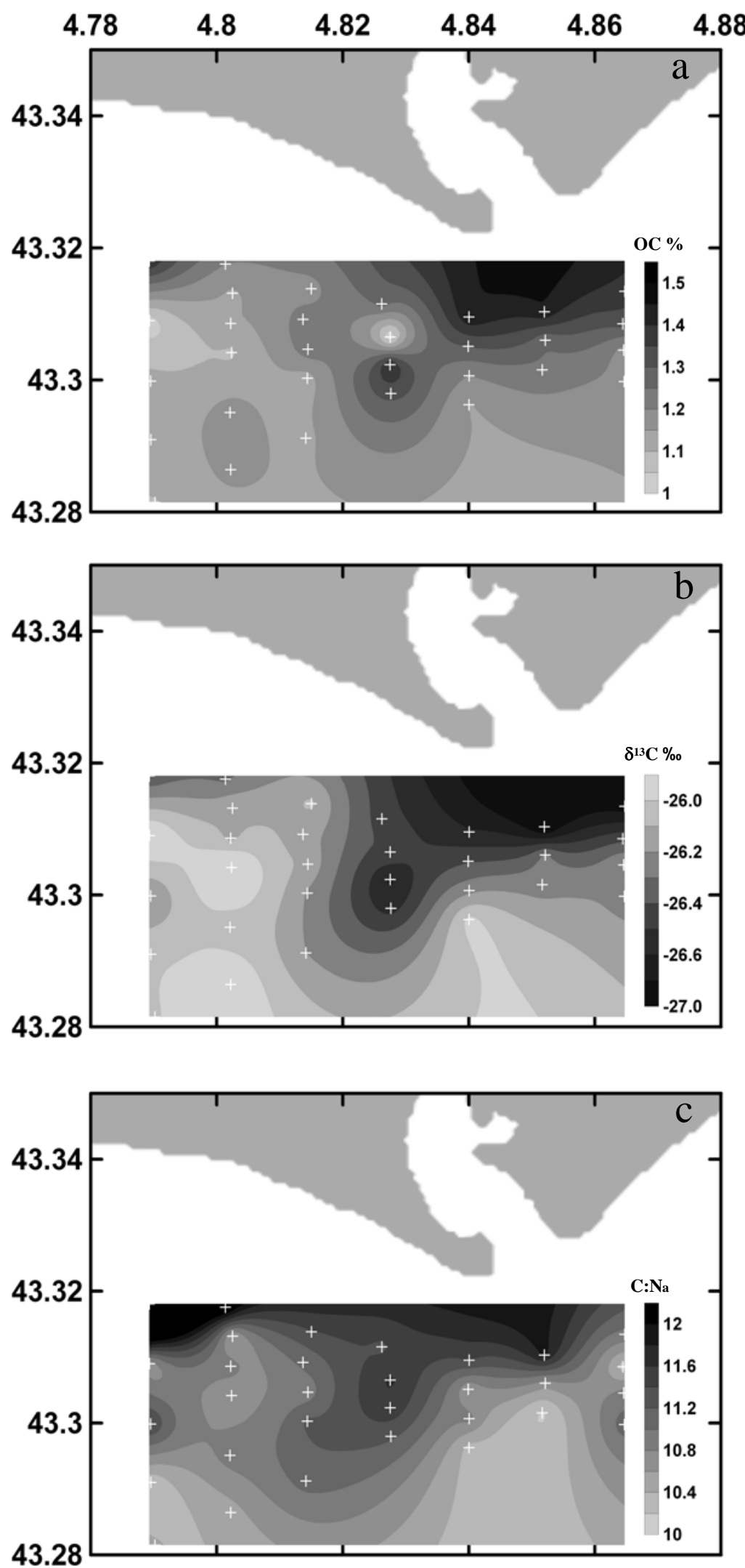

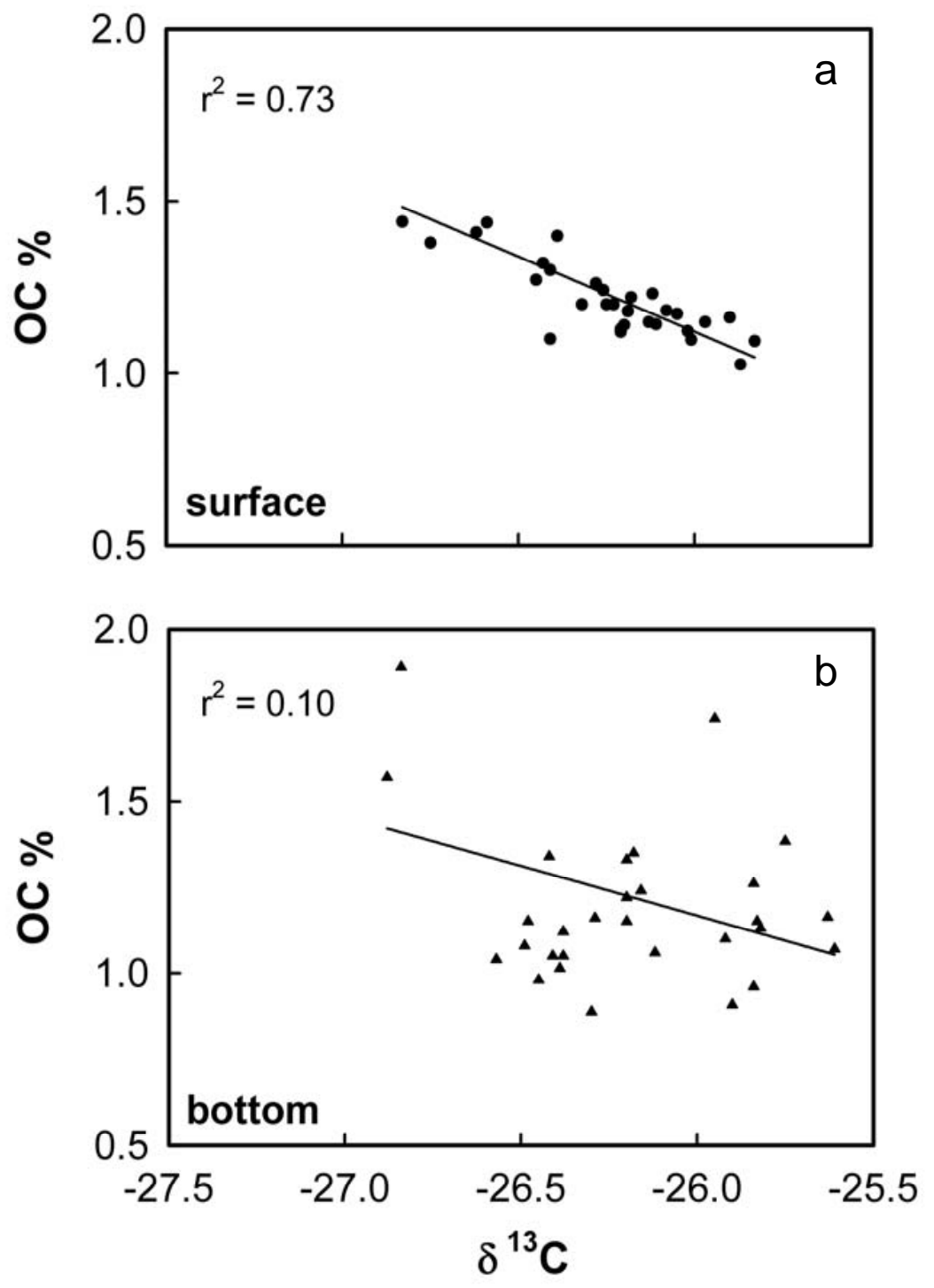


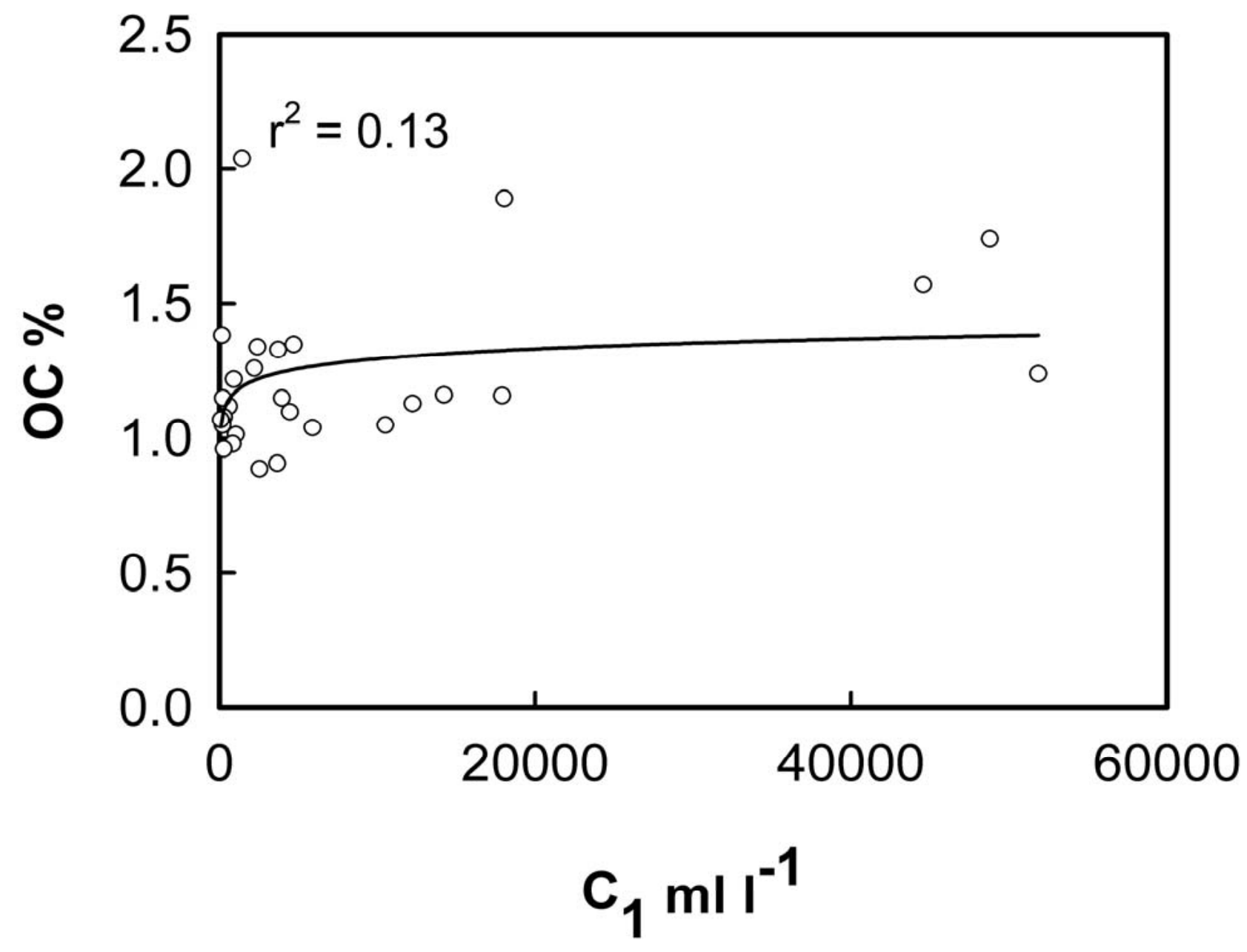




\section{OCTOBER 05}

\begin{tabular}{|c|c|c|c|c|c|c|c|c|c|c|c|c|}
\hline SITE & $\begin{array}{l}\text { CORE } \\
\text { TYPE }\end{array}$ & $\begin{array}{l}\text { WD } \\
\text { (m) }\end{array}$ & $\begin{array}{c}\text { SD } \\
\text { (cm b.s.f.) }\end{array}$ & C1 & $\begin{array}{c}\mathrm{C2} \\
(\mathrm{mL} / \mathrm{L})\end{array}$ & C3 & C1 & $\begin{array}{l}\text { C2 } \\
\quad(p p m)\end{array}$ & C3 & $\mathrm{CO} 2$ & $\begin{array}{l}\delta 13 \mathrm{C} \\
\text { (CH4) }\end{array}$ & $\begin{array}{l}\delta 13 \mathrm{C} \\
(\mathrm{CO} 2)\end{array}$ \\
\hline ke28 150 & " KC & 28 & ב 150 & 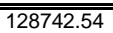 & $\begin{array}{ll}0.00 \\
\end{array}$ & ב3.31 & 82150 & $\begin{array}{l}0.00 \\
\end{array}$ & 2.11 & 21910 & $\begin{array}{ll}\text { sent } \\
\end{array}$ & \\
\hline ke28 205 & $\mathrm{KC}$ & 28 & 205 & 127516.67 & 0.00 & 2.76 & 87440 & 0.00 & 1.89 & 46180 & sent & \\
\hline ke33 216 & KC & 33 & 216 & 127457.46 & 0.00 & 3.39 & 81330 & 0.00 & 2.16 & 36310 & sent & \\
\hline ke28 100 & $\mathrm{KC}$ & 28 & 100 & 77595.58 & 0.00 & 1.17 & 66880 & 0.00 & 1.01 & 24640 & sent & \\
\hline e33 & $\mathrm{BC}$ & 33 & 30 & 51852.13 & 0.20 & 2.26 & 23210 & 0.09 & 1.01 & 88660 & sent & \\
\hline f58b & $\mathrm{BC}$ & 58 & 30 & 48775.18 & 0.36 & 1.53 & 31820 & 0.24 & 1.00 & 43330 & sent & \\
\hline g31 & $\mathrm{BC}$ & 31 & 40 & 44570.69 & 0.02 & 1.00 & 36930 & 0.02 & 0.83 & 44520 & sent & \\
\hline ke33 160 & $\mathrm{KC}$ & 33 & 160 & 41423.78 & 0.38 & 4.88 & 32350 & 0.30 & 3.81 & 21980 & sent & \\
\hline ke33 105 & $\mathrm{KC}$ & 33 & 105 & 31029.31 & 0.20 & 1.61 & 25710 & 0.16 & 1.34 & 34640 & sent & \\
\hline $\mathrm{f} 32$ & $\mathrm{BC}$ & 31 & 28 & 18043.69 & 0.03 & 0.35 & 8850 & 0.02 & 0.17 & 9960 & sent & \\
\hline h30 & $\mathrm{BC}$ & 30 & 17 & 17915.04 & 0.26 & 2.21 & 9640 & 0.14 & 1.19 & 52980 & sent & \\
\hline e56 & $\mathrm{BC}$ & 56 & 28 & 14227.50 & 1.26 & 2.41 & 5420 & 0.48 & 0.92 & 32270 & sent & \\
\hline j63 & $\mathrm{BC}$ & 63 & 28 & 12240.00 & 0.42 & 0.66 & 10200 & 0.35 & 0.55 & 28980 & sent & \\
\hline f47 & $\mathrm{BC}$ & 47 & 30 & 10516.94 & 0.29 & 1.24 & 6210 & 0.17 & 0.73 & 14710 & sent & \\
\hline e48b & $\mathrm{BC}$ & 48 & 34 & 5903.77 & 0.27 & 0.78 & 4470 & 0.20 & 0.59 & 10000 & sent & \\
\hline e65 & $\mathrm{BC}$ & 65 & 32 & 4717.16 & 1.93 & 1.60 & 3010 & 1.23 & 1.02 & 18050 & sent & \\
\hline i50 & $\mathrm{BC}$ & 51 & 30 & 4479.02 & 1.10 & 1.15 & 3050 & 0.75 & 0.78 & 13340 & sent & \\
\hline g47 & $\mathrm{BC}$ & 47 & 33 & 3964.93 & 1.05 & 1.62 & 2530 & 0.67 & 1.03 & 22270 & sent & \\
\hline j52 & $\mathrm{BC}$ & 52 & 30 & 3955.48 & 3.29 & 0.56 & 2750 & 2.29 & 0.39 & 16420 & sent & \\
\hline i 42 & $\mathrm{BC}$ & 42 & 32 & 3725.13 & 0.73 & 0.54 & 3530 & 0.69 & 0.51 & 8100 & sent & \\
\hline i68 & $\mathrm{BC}$ & 68 & 35 & 3668.52 & 2.04 & 0.53 & 2830 & 1.58 & 0.41 & 8800 & sent & \\
\hline f58s & $\mathrm{BC}$ & 58 & 0 & 3049.32 & 3.47 & 14.48 & 1060 & 1.21 & 5.04 & 11020 & sent & \\
\hline g57 & $\mathrm{BC}$ & 57 & 41 & 2538.04 & 1.26 & 1.04 & 1970 & 0.98 & 0.81 & 28690 & sent & \\
\hline i32 & $\mathrm{BC}$ & 32 & 25 & 2415.00 & 1.95 & 0.73 & 1840 & 1.49 & 0.56 & 19800 & sent & \\
\hline i58 & $\mathrm{BC}$ & 58 & 35 & 2226.85 & 1.50 & 1.12 & 1580 & 1.07 & 0.80 & 18910 & sent & \\
\hline g65 & $\mathrm{BC}$ & 65 & 38 & 1442.75 & 2.07 & 0.87 & 900 & 1.29 & 0.54 & 11990 & sent & \\
\hline h62 & $\mathrm{BC}$ & 62 & 33 & 1124.88 & 2.75 & 0.93 & 691 & 1.69 & 0.57 & 35100 & sent & \\
\hline k72 & $\mathrm{BC}$ & 72 & 42 & 1052.59 & 0.48 & 0.39 & 812 & 0.37 & 0.30 & 4400 & sent & \\
\hline j36 & $\mathrm{BC}$ & 36 & 33 & 907.08 & 2.01 & 0.43 & 622 & 1.38 & 0.30 & 14330 & sent & \\
\hline h45 & $\mathrm{BC}$ & 45 & 29 & 841.19 & 1.05 & 1.11 & 709 & 0.88 & 0.94 & 11110 & sent & \\
\hline j46 & $\mathrm{BC}$ & 46 & 38 & 614.02 & 1.21 & 0.30 & 538 & 1.06 & 0.26 & 9610 & sent & \\
\hline h56 & $\mathrm{BC}$ & 56 & 33 & 291.86 & 0.70 & 0.72 & 246 & 0.59 & 0.61 & 13690 & sent & \\
\hline j70 & $\mathrm{BC}$ & 72 & 32 & 279.22 & 2.88 & 0.30 & 238 & 2.45 & 0.26 & 12700 & sent & \\
\hline k65 & $\mathrm{BC}$ & 65 & 34 & 233.66 & 1.28 & 0.35 & 158 & 0.86 & 0.24 & 16470 & & \\
\hline k28 & $\mathrm{BC}$ & 28 & 30 & 212.22 & 0.69 & 0.20 & 191 & 0.62 & 0.18 & 3040 & & \\
\hline j28 & $\mathrm{BC}$ & 28 & 32 & 207.06 & 0.63 & 0.28 & 211 & 0.64 & 0.29 & 3110 & sent & \\
\hline $\mathrm{k} 43$ & $\mathrm{BC}$ & 43 & 31 & 170.45 & 1.16 & 0.20 & 125 & 0.85 & 0.15 & 6970 & & \\
\hline k57 & $\mathrm{BC}$ & 57 & 35 & 92.79 & 0.69 & 0.21 & 57 & 0.43 & 0.13 & 2240 & & \\
\hline
\end{tabular}

\section{FEB-MAR 04}

\begin{tabular}{|c|c|c|c|c|c|c|c|c|c|c|c|c|}
\hline SITE & $\begin{array}{l}\text { CORE } \\
\text { TYPE }\end{array}$ & $\begin{array}{l}\text { WD } \\
(\mathrm{m})\end{array}$ & $\begin{array}{c}\text { SD } \\
\text { (cm b.s.f.) } \\
\end{array}$ & C1 & $\begin{array}{c}\mathrm{C2} \\
(\mathrm{mL} / \mathrm{L}) \\
\end{array}$ & C3 & C1 & $\begin{array}{l}\mathrm{C} 2 \quad \text { (ppm) } \\
\end{array}$ & C3 & $\mathrm{CO} 2$ & $\begin{array}{l}\delta 13 \mathrm{C} \\
\text { (CH4) } \\
\end{array}$ & $\begin{array}{l}\delta 13 C \\
(\mathrm{CO} 2) \\
\end{array}$ \\
\hline$\overline{\mathrm{BF} 05}$ & FC & 27 & 25 & 9852.91 & "0.00 & 0.64 & 16140 & $\overline{0.00}$ & 1.05 & 35320 & -59.9 & -29.5 \\
\hline BF06 & FC & 28 & 25 & 2544.48 & 0.16 & 0.39 & 3950 & 0.24 & 0.61 & 24630 & -53.1 & -30.5 \\
\hline BF07 & FC & 43 & 25 & 836.17 & 1.01 & 1.44 & 1310 & 1.58 & 2.25 & 19170 & -81.9 & -25.8 \\
\hline BF09 & FC & 30 & 25 & 4838.83 & 0.20 & 0.43 & 7120 & 0.29 & 0.63 & 35560 & -53.2 & -31.3 \\
\hline BF18 & FC & 60 & 25 & 417.79 & 0.44 & 0.26 & 591 & 0.63 & 0.36 & 5410 & -69.9 & -22.7 \\
\hline BF20 & FC & $20 ?$ & 25 & 276.32 & 0.93 & 0.45 & 370 & 1.24 & 0.61 & 3050 & -67.5 & -22.6 \\
\hline BF14 & FC & 57 & 25 & 411.91 & 1.19 & 1.05 & 532 & 1.54 & 1.35 & 2920 & -68.5 & -17.8 \\
\hline BF90 & FC & 94 & 25 & 210.61 & 0.41 & 0.60 & 313 & 0.61 & 0.90 & 5220 & & \\
\hline BF50 & FC & 95 & 25 & 88.33 & 0.57 & 0.96 & 117 & 0.75 & 1.27 & 4370 & & \\
\hline Chenal 30 & FC & $30 ?$ & 45 & 27878.74 & 0.00 & 0.70 & 33720 & 0.00 & 0.85 & 37860 & -67.5 & -30.0 \\
\hline BF16KB & FC & 14 & 40 & 423.77 & 1.25 & 0.62 & 480 & 1.42 & 0.70 & 22160 & & \\
\hline BF19 & FC & 76 & 25 & 48.70 & 0.80 & 0.27 & 48 & 0.78 & 0.27 & 2820 & & \\
\hline BF22 & FC & 74 & 25 & 9.59 & 0.29 & 0.09 & 10 & 0.30 & 0.09 & 2800 & & \\
\hline BF101 & FC & 76 & 25 & 248.88 & 1.29 & 0.50 & 230 & 1.19 & 0.46 & 9320 & & \\
\hline BF102 & $\mathrm{FC}$ & 80 & 25 & 219.59 & 3.49 & 0.40 & 225 & 3.57 & 0.41 & 5400 & & \\
\hline BF04 & $\mathrm{FC}$ & 86 & 25 & 6.66 & 0.42 & 0.15 & 8 & 0.49 & 0.17 & 2570 & & \\
\hline R4 & $\mathrm{FC}$ & 47 & 25 & 9.65 & 1.88 & 0.20 & 9 & 1.76 & 0.19 & 2740 & & \\
\hline BF01bis & FC & 26 & 25 & 229.83 & 0.21 & 0.22 & 239 & 0.22 & 0.23 & 1110 & & \\
\hline
\end{tabular}




\begin{tabular}{|c|c|c|c|c|c|c|c|c|c|}
\hline \multirow[b]{2}{*}{ Station } & \multirow[b]{2}{*}{ core depth $(\mathrm{cm})$} & \multicolumn{4}{|c|}{ Surface } & \multicolumn{4}{|c|}{ Bottom } \\
\hline & & OC \% & NT \% & $d^{13} C$ & $\mathrm{C}: \mathrm{N}_{\mathrm{a}}$ & OC \% & NT \% & $d^{13} C$ & $\mathrm{C}: \mathrm{Na}$ \\
\hline E 33 & 30 & 1.38 & 0.147 & -26.75 & 10.94 & 1.24 & 0.14 & -26.16 & 10.63 \\
\hline E 48B & 34 & 1.32 & 0.149 & -26.43 & 10.31 & 1.04 & 0.10 & -26.57 & 12.04 \\
\hline E 56 & 28 & 1.18 & 0.13 & -26.19 & 10.89 & 1.16 & 0.13 & -25.63 & 10.27 \\
\hline E 65 & 32 & 1.20 & 0.126 & -26.25 & 11.11 & 1.35 & 0.14 & -26.18 & 11.29 \\
\hline F 32 & n.d. ${ }^{a}$ & 1.44 & 0.14 & -26.83 & 11.85 & 1.89 & 0.19 & -26.84 & 11.32 \\
\hline F 47 & 30 & 1.26 & 0.138 & -26.28 & 10.70 & 1.05 & 0.11 & -26.41 & 11.19 \\
\hline F 58 & 30 & 1.24 & 0.142 & -26.26 & 10.18 & 1.74 & 0.16 & -25.95 & 12.68 \\
\hline G 31 & n.d. ${ }^{a}$ & 1.44 & 0.147 & -26.59 & 11.42 & 1.57 & 0.16 & -26.88 & 11.48 \\
\hline G 47 & 33 & 1.30 & 0.143 & -26.41 & 10.62 & 1.15 & 0.12 & -26.48 & 11.21 \\
\hline G 57 & 30 & 1.20 & 0.129 & -26.23 & 10.86 & 0.89 & 0.10 & -26.30 & 10.46 \\
\hline G 65 & 36 & 1.15 & 0.130 & -25.97 & 10.33 & 2.04 & 0.22 & -26.67 & 10.81 \\
\hline H 30 & n.d. ${ }^{a}$ & 1.27 & 0.130 & -26.45 & 11.36 & 1.16 & 0.12 & -26.29 & 12.60 \\
\hline H 45 & 29 & 1.10 & 0.101 & -26.41 & 11.63 & 0.98 & 0.11 & -26.45 & 10.68 \\
\hline H 56 & 33 & 1.41 & 0.142 & -26.62 & 11.55 & 1.08 & 0.12 & -26.49 & 10.42 \\
\hline H 62 & 33 & n.d. ${ }^{a}$ & 0.152 & -26.54 & n.d. ${ }^{a}$ & 1.48 & 0.17 & -26.41 & 10.46 \\
\hline I 32 & 25 & 1.18 & 0.121 & -26.08 & 11.39 & 1.34 & 0.14 & -26.42 & 11.32 \\
\hline I 42 & 32 & 1.22 & 0.129 & -26.18 & 11.05 & 1.33 & 0.14 & -26.20 & 10.76 \\
\hline 150 & 30 & 1.23 & 0.132 & -26.12 & 10.89 & 1.10 & 0.12 & -25.92 & 10.82 \\
\hline 158 & 35 & 1.13 & 0.117 & -26.21 & 11.24 & 1.26 & 0.13 & -25.84 & 11.17 \\
\hline 168 & 35 & 1.14 & 0.12 & -26.20 & 11.08 & 0.91 & 0.10 & -25.90 & 10.71 \\
\hline J 28 & n.d. ${ }^{a}$ & 1.20 & 0.11 & -26.32 & 12.38 & 1.05 & 0.10 & -26.38 & 12.55 \\
\hline J 36 & n.d. ${ }^{a}$ & 1.14 & 0.126 & -26.11 & 10.55 & 1.22 & 0.12 & -26.20 & 11.74 \\
\hline J 46 & 38 & 1.15 & 0.123 & -26.13 & 10.90 & 1.12 & 0.12 & -26.38 & 10.82 \\
\hline J 52 & 30 & 1.09 & 0.120 & -25.85 & 10.66 & 1.15 & 0.13 & -26.20 & 10.66 \\
\hline J 63 & n.d. ${ }^{a}$ & 1.17 & 0.126 & -26.05 & 10.89 & 1.13 & 0.13 & -25.82 & 10.33 \\
\hline J 70 & n.d. ${ }^{a}$ & 1.16 & 0.129 & -25.90 & 10.52 & 0.96 & 0.11 & -25.84 & 10.29 \\
\hline K 28 & n.d. ${ }^{a}$ & 1.40 & n.d. ${ }^{a}$ & -26.39 & n.d. ${ }^{a}$ & 1.06 & 0.10 & -26.12 & 12.37 \\
\hline K 43 & 31 & 1.03 & 0.112 & -25.87 & 10.65 & 1.38 & 0.15 & -25.75 & 10.48 \\
\hline K 57 & 35 & 1.12 & 0.11 & -26.21 & 11.43 & 1.07 & 0.12 & -25.61 & 10.85 \\
\hline K 65 & 34 & 1.12 & 0.128 & -26.02 & 10.24 & 1.15 & 0.13 & -25.83 & 10.65 \\
\hline K 72 & 42 & 1.10 & 0.123 & -26.01 & 10.42 & 1.01 & 0.12 & -26.39 & 9.78 \\
\hline
\end{tabular}




\begin{tabular}{|c|c|c|c|c|c|c|c|c|c|c|c|c|c|}
\hline \multirow[b]{2}{*}{ depth } & \multirow[b]{2}{*}{$n$} & \multirow[b]{2}{*}{ average } & \multirow[b]{2}{*}{ d.s } & \multicolumn{2}{|c|}{ OC \% } & \multirow[b]{2}{*}{ average } & \multicolumn{2}{|c|}{$\delta^{13} \mathrm{C} \%$} & \multicolumn{4}{|c|}{$\mathrm{C}: \mathrm{N}_{\mathrm{a}}$} & \multirow[b]{2}{*}{$\min$} \\
\hline & & & & $\max$ & $\min$ & & d.s. & $\max$ & $\min$ & average & d.s. & $\max$ & \\
\hline top & 31 & 1.22 & 0.11 & 1.44 & 1.03 & -26.25 & 0.25 & -25.85 & -26.83 & 11.04 & 0.63 & 13.04 & 10.3 \\
\hline bottom & 31 & 1.24 & 0.27 & 2.04 & 0.89 & -26.21 & 0.34 & -25.61 & -26.88 & 11.10 & 0.76 & 12.68 & 9.78 \\
\hline
\end{tabular}

